\title{
Subacute Oral Administration of Clinacanthus nutans Ethanolic Leaf Extract Induced Liver and Kidney Toxicities in ICR Mice
}

\author{
Abdullahi Aliyu ${ }^{1,2, *(\mathbb{C}) \text {, Mohd Rosly Shaari }}{ }^{3}$, Nurul Syahirah Ahmad Sayuti ${ }^{1}$, \\ Mohd Farhan Hanif Reduan ${ }^{1}$, Shanmugavelu Sithambaram ${ }^{3}$, Mustapha Mohamed Noordin ${ }^{1} \mathbb{B}$, \\ Khozirah Shaari ${ }^{4,5}$ and Hazilawati Hamzah $1, *$ (D) \\ 1 Department of Veterinary Pathology and Microbiology, Faculty of Veterinary Medicine, \\ Universiti Putra Malaysia, Serdang 43400, Selangor, Malaysia; nurulsyahirah0806@gmail.com (N.S.A.S.); \\ farhan.h@umk.edu.my (M.F.H.R.); noordinmm@upm.edu.my (M.M.N.) \\ 2 Department of Veterinary Pathology, Faculty of Veterinary Medicine, City Campus Complex, \\ Usmanu Danfodiyo University, Sokoto 840212, Sokoto State, Nigeria \\ 3 Animal Science Research Centre, Malaysian Agricultural Research and Development Institute Headquarter, \\ Serdang 43400, Selangor, Malaysia; rosly@mardi.gov.my (M.R.S.); shan.sithambaram@gmail.com (S.S.) \\ 4 Department of Chemistry, Faculty of Science and Environmental Studies, Universiti Putra Malaysia, \\ Serdang 43400, Selangor, Malaysia; khozirah@upm.edu.my \\ 5 Laboratory of Natural Products, Institute of Bioscience, Universiti Putra Malaysia, \\ Serdang 43400, Selangor, Malaysia \\ * Correspondence: abdullahi.aliyu@udusok.edu.ng (A.A.); hazilawati@upm.edu.my (H.H.)
}

Received: 27 March 2020; Accepted: 27 April 2020; Published: 5 June 2020

\begin{abstract}
This study investigated the leaves of Clinacanthus nutans for its bioactive compounds and acute and subacute toxicity effects of $C$. nutans ethanolic leaf extract (CELE) on blood, liver and kidneys of ICR mice. A total of 10 8-week-old female mice were divided into groups A (control) and B $(2000 \mathrm{mg} / \mathrm{kg})$ for the acute toxicity study. A single dose of $2000 \mathrm{mg} / \mathrm{kg}$ was administered to group B through oral gavage and mice were monitored for 14 days. In the subacute toxicity study, mice were divided into five groups: A (control), B (125 mg/kg), C (250 mg/kg), D (500 mg/kg) and E (1000 mg/kg). The extract was administered daily for 28 days via oral gavage. The mice were sacrificed, and samples were collected for analyses. Myricetin, orientin, isoorientin, vitexin, isovitexin, isookanin, apigenin and ferulic acid were identified in the extract. Twenty-eight days of continuous oral administration revealed significant increases $(p<0.05)$ in creatinine, ALT and moderate hepatic and renal necrosis in groups $\mathrm{D}$ and $\mathrm{E}$. The study concluded that the lethal dose $\left(\mathrm{LD}_{50}\right)$ of CELE in mice is greater than $2000 \mathrm{mg} / \mathrm{kg}$ and that repeated oral administrations of CELE for 28 days induced hepatic and renal toxicities at $1000 \mathrm{mg} / \mathrm{kg}$ in female ICR mice.
\end{abstract}

Keywords: Clinacanthus nutans; myricetin; isookanin; orientin; vitexin; ICR mice; acute toxicity; subacute toxicity; histopathology; biochemical parameters

\section{Introduction}

The use of plant-based products in both traditional and modern societies as herbal remedies or crude drugs, or as purified compounds have a long history [1]. Phytoresearches provide significant classes of drugs that are used in the treatment of various illnesses in both humans and animals including cancers, malaria, HIV/AIDS and diabetes. In the recent past, medicinal plants, such as C. nutans, are gaining increasing attention in both traditional and modern societies [1]. Most of these plants are widely distributed and consumed globally, particularly in developing countries, where 
larger proportion depend on plants and their products for their primary health care challenges [2] and chronic diseases. This is perhaps because of poverty, the increasing cost of modern medicines and little awareness of the plants' side effects [3].

Clinacanthus nutans is a known herbal plant that belongs to the family Acanthaceae, which consists of 250 genera and about 2500 species, which are mostly tropical herbs or shrubs, and epiphytes in some cases [2]. The genus Clinacanthus consists of two species, C. nutans (Burm. F.) Lindau and C. siamensis Bremek, both of which are found throughout Southeast Asia. The two species have different pharmacological characteristics, molecular aspect and anti-herpes simplex virus (HSV) types 1 and 2 activities [4]. C. nutans is locally known as "Sabah snake grass" or "rumput belalai gajah" (in Malaysia), "Phayo yo" (in Thailand) and "Dandang Gendis" (in Indonesia) [5]. The plant has been initially used to treat poisonous snake bites; however, it was later identified to possess potential antiviral properties [6]. It is traditionally used in Thailand for the treatment of various illnesses including cancers, skin rashes, snake and insects bites, diabetes mellitus, diarrhoea, as an anti-viral agent against HSV and varicella-zoster virus (VZV) [2,7]. The mechanism of action of this plant is attributed to its anti-cell lysis property rather than an antineuromuscular transmission blocker [6]. The wide range of pharmacological activities associated with $C$. nutans could be attributed to the bioactive compounds reported in different parts of the plant, including saponins, glycosides, steroids and flavonoids [8,9]. Recently, Hao et al. [10] reported that preparations of silver and gold nanoparticles using aqueous leaf extract of $C$. nutans Lindau demonstrated higher analgesic and muscle relaxant activities at concentrations of 50,100 and $150 \mathrm{mg} / \mathrm{kg}$ body weight in BALB/c mice, compared to the methanolic extract of the plant at concentrations of 100, 200 and $400 \mathrm{mg} / \mathrm{kg}$ [10].

Toxicity evaluation of $C$. nutans therefore becomes very necessary in order to ascertain its safety levels that should be used for the treatment of various illnesses. The current literature mostly reported the toxicity effects of the aqueous leaf extracts of the plants [11,12], while a few others that employed the methanolic/ethanolic leaf extracts reported that the plant is not associated with toxicity effects mostly based on the evaluation of body weight changes, haematological and serum biochemical parameters $[9,13,14]$, while the effects of the extracts on the histology of liver and kidneys, which were the primary organs involved in the detoxification and excretion of potential toxic substances from the body, were not reported.

Murugesu at al. [15] investigated the in vitro toxic effect and the lethal concentration of non-polar fraction of $C$. nutans at concentrations of $15.63,31.25,62.5,125,250$ and $500 \mu \mathrm{g} / \mathrm{mL}$ on zebrafish embryos at $72 \mathrm{hpf}$. The results showed that the median lethal concentration $\left(\mathrm{LC}_{50}\right)$ was found to be 75.49 , which was harmful [15] according to the organization for economic co-operation and development (OECD) guideline. The concentration of $500 \mu \mathrm{g} / \mathrm{mL}$ was toxic to the embryos showing $100 \%$ mortality after $24 \mathrm{~h}$. Other malformations reported by Murugesu et al. [15] due to hexane extract of $C$. nutans in zebrafish embryos included spinal curvature, oedema, malformed yolk sac, as well as reduced hatchability and growth retardation [15]. These in vitro toxic lesions make it necessary to study further the in vivo toxicity effects of $C$. nutans extract in laboratory animals.

Currently, there is paucity of information on the bioactive compounds, nutritional composition and toxicity effects of $C$. nutans cultivated in Pahang-Malaysia. Some of the previous studies $[3,9]$ reported the groups of phytochemical compounds (e.g., saponins, glycosides, steroids, flavonoids, etc.) in C. nutans. However, the specific phytocompounds in this plant cultivated in Pahang-Malaysia have not been adequately investigated. Besides, there is no uniformity in the previous reports that investigated the phytochemical compounds of the plant [16-18], possibly due to the differences in agro-climatic conditions, genetic factors, differences in cultivation techniques, drying and extraction methods employed $[19,20]$. Förster et al. [21] reported that the secondary metabolites of plants are highly susceptible to various environmental conditions, including temperature regulation, water quality and cycling, carbon and nutrient cycle, etc. This makes it necessary to verify the phytochemical compounds of medicinal plants in each field trial in the various cultivation areas [21]. 
Consequently, this study investigated the bioactive compounds of $C$. nutans ethanolic leaf extract cultivated and collected from Pahang-Malaysia using a liquid chromatography-electrospray ion mass spectrometer (LCESI-MS/MS). Moreover, the detailed effects of single as well as repeated oral administration of CELE on the blood parameters as well as histology of liver and kidney of female institute of cancer research (ICR) mice were investigated in this study. This study would provide reliable data on the bioactive compounds of $C$. nutans cultivated in Pahang-Malaysia, at the same time provide details possible toxic effects of CELE on the histology of liver and kidneys of female ICR mice, which could be useful as a guide in selecting appropriate doses for future treatment studies using the plant extract.

\section{Results}

\subsection{Liquid Chromatography-Mass Spectrometry (LC-MS)}

The total ion chromatograms (TIC) of the compounds identified in the sample of Clinacanthus nutans ethanolic leaf extract (CELE) are demonstrated in Figure 1. The identities of eight compounds were determined along with their retention time, protonated molecular ions and characteristic fragment ions (Table 1). The compounds identified based on the LC-MS and MS/MS data analysis include myricetin, orientin, isoorientin, vitexin, isovitexin, isookanin, apigenin and ferulic acid (Table 1). The total ion chromatogram and the structure of the eight compounds identified are presented below, in Figures 1-9. The compounds were identified by comparing their masses $(m / z)$, fragment ions and mass spectra with those reported in the mass bank (metabolite database).

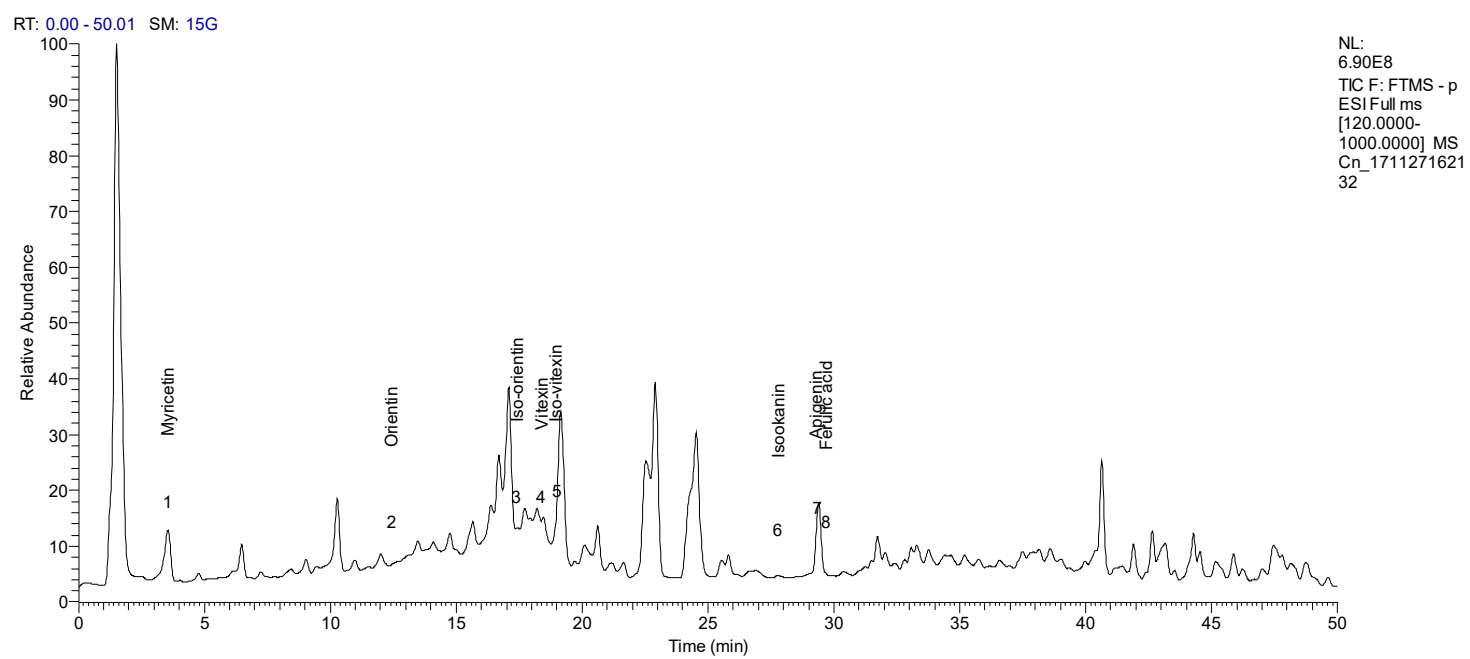

Figure 1. Total ion chromatograms (TIC) of the compounds in Clinacanthus nutans ethanolic leaf extract (CELE).

Table 1. Bioactive compounds detected in Clinacanthus nutans ethanolic leaf extract (CELE).

\begin{tabular}{ccccc}
\hline $\mathbf{S} / \mathbf{N}$ & $\begin{array}{c}\mathbf{R t} \\
(\mathbf{m i n})\end{array}$ & $\begin{array}{c}\text { Tentative } \\
\text { Compounds }\end{array}$ & {$[\mathbf{M}-\mathbf{H}]^{-}(\mathbf{m} / \mathbf{z})$} & Fragment Ions \\
\hline 1 & 3.47 & Myricetin & 317.0465 & $99,112,116,136,145,152,161,180,183,198,220,228$ \\
2 & 13 & Orientin & 447.0912 & $269.1028,285.0403,299.0561,311.0564,327.0513$ \\
3 & 17.27 & Iso orientin & 447.0912 & $327,357,299,285$ \\
4 & 17.45 & Vitexin & 431.0981 & $117.0331,161.0232,283.0612,311.0563,341.0667$ \\
5 & 18.48 & Isovitexin & 431.0981 & $283,311,269,323,341$ \\
6 & 27.44 & Isookanin & 287.1218 & $89,93,151,154,169,170,178$ \\
7 & 28.48 & Apigenin & 269.0455 & $151,159,117,107$ \\
8 & 30.93 & Ferulic acid & 193.0863 & $63,79,80,89,163,177,178$ \\
\hline
\end{tabular}


Cn $171127162132 \# 615$ RT: 3.47 AV: 1 NL: $1.23 E 4$

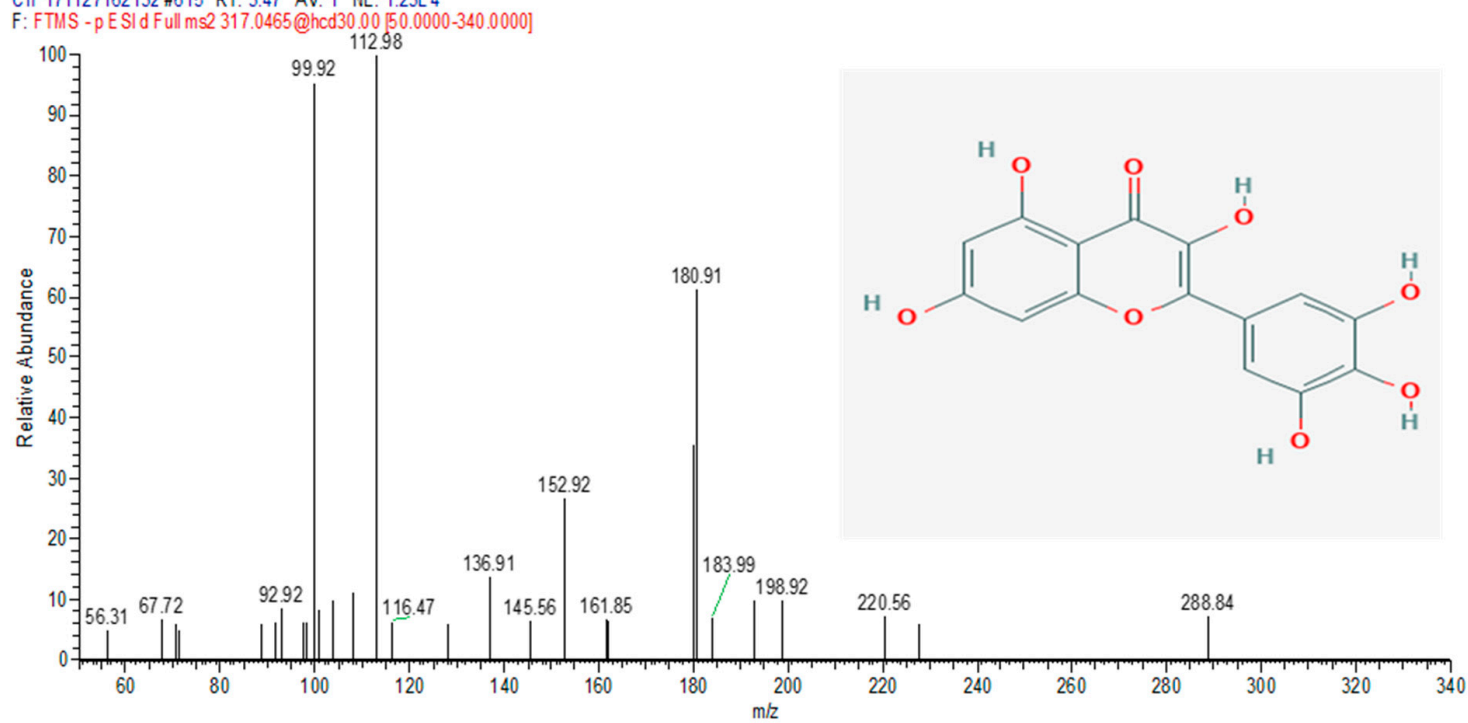

Figure 2. Myricetin.

Cn $171127162132 \# 2323$ RT: 13.00 AV: 1 NL: 3.40 E5

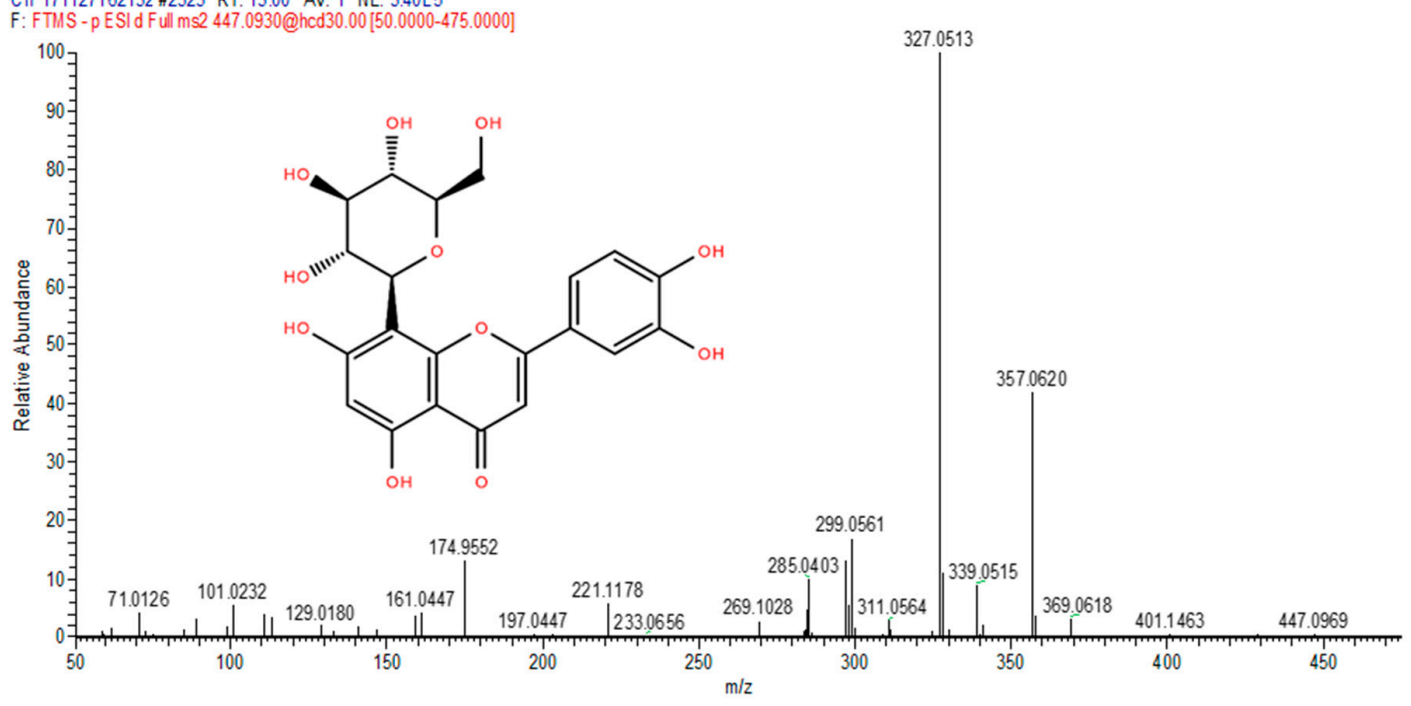

Figure 3. Orientin. 
Cn_171127162132 \#3095 RT: 17.27 AV: 1 NL: 2.08E6

F: FTMS - p ESId Full ms2 447.0930@hod 30.00 [50.00000-475.0000]

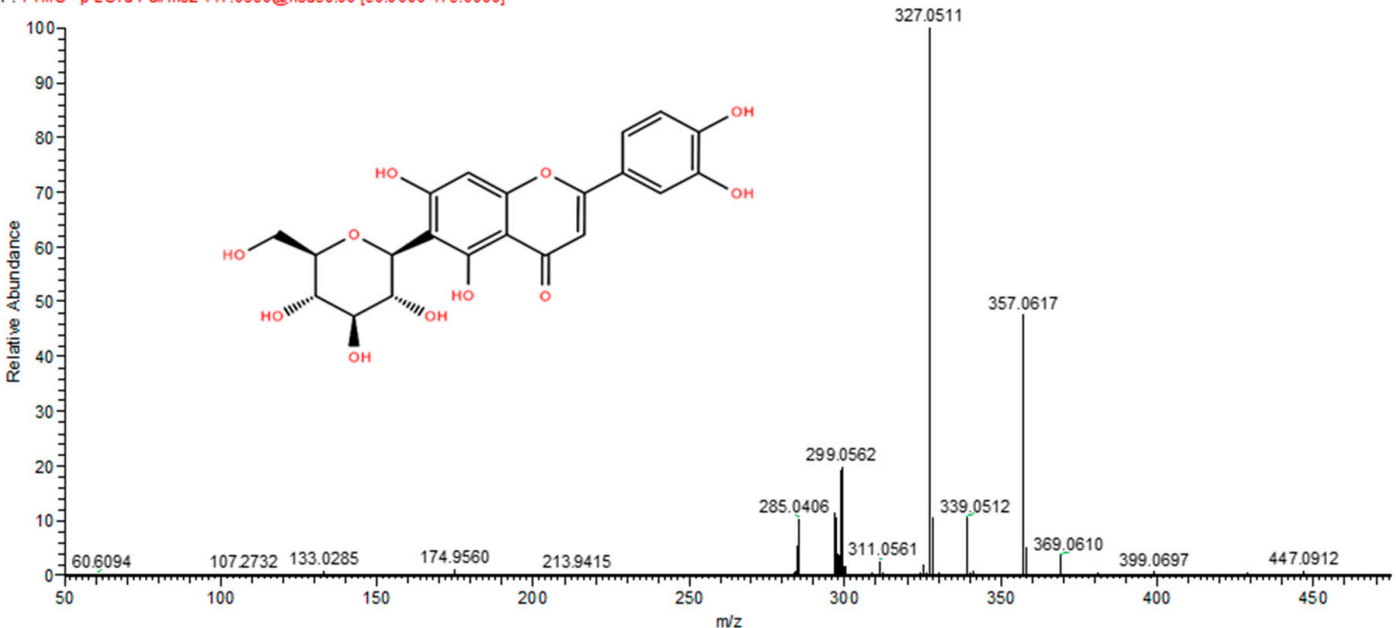

Figure 4. Isoorientin.

Cn 171127162132 \#3123 RT: 17.42 AV: 1 NL: 3.54 E 6

F: FTMS - p ESId Full ms2 431.0981@hod30.00 [50.0000-460.0000]

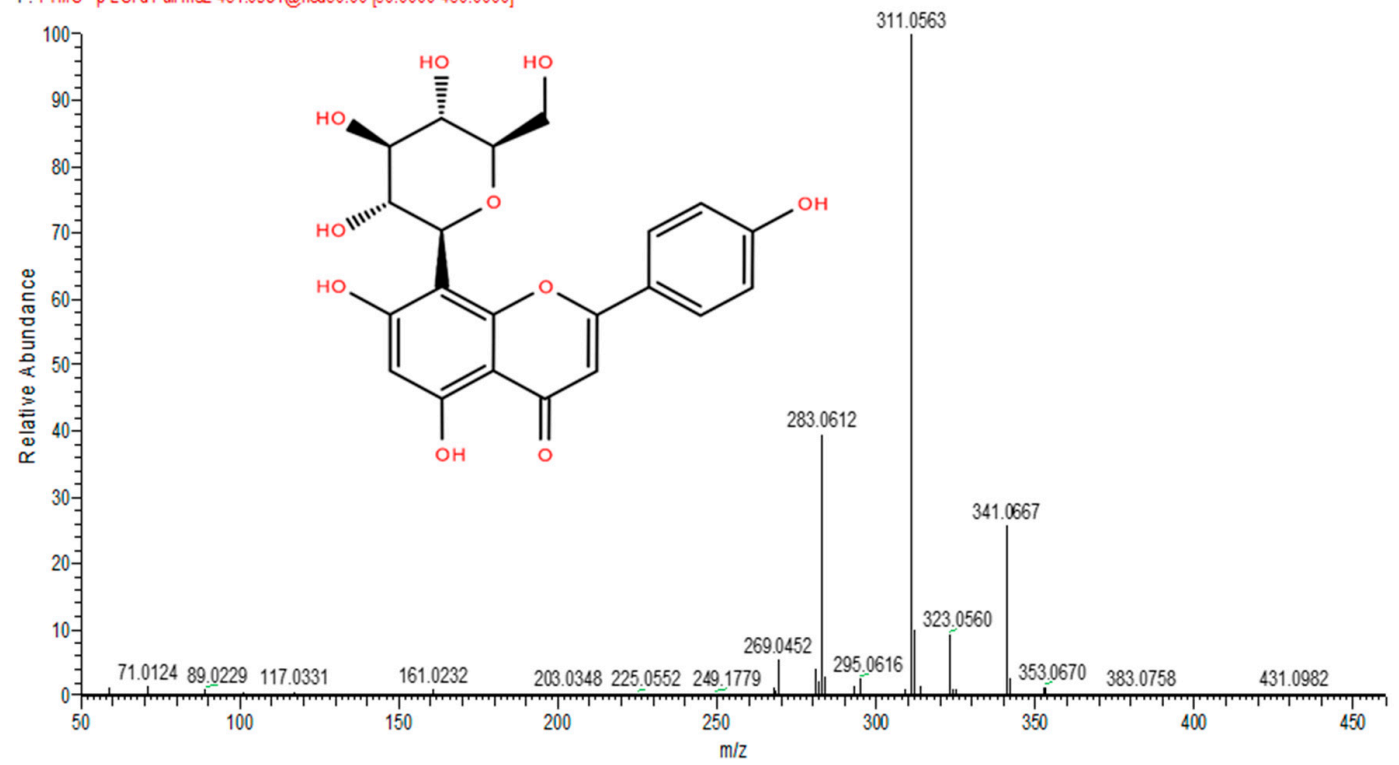

Figure 5. Vitexin. 


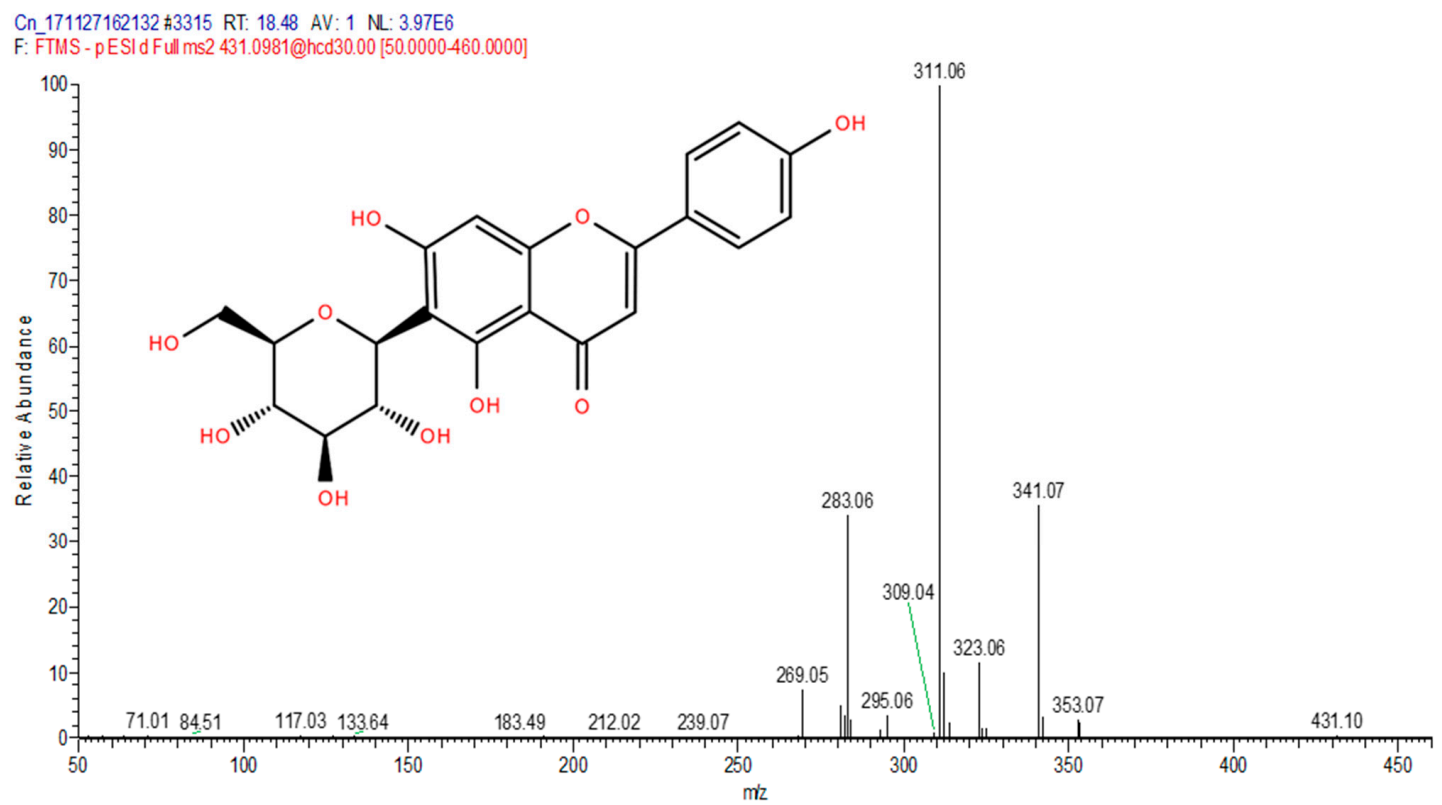

Figure 6. Isovitexin.

Cn_171127162132 \#4903 RT: 27.44 AV: 1 NL: $9.25 E 4$

F: FTMS-p ESI d Full ms2 287.1218@hod30.00 [50.0000-310.0000]

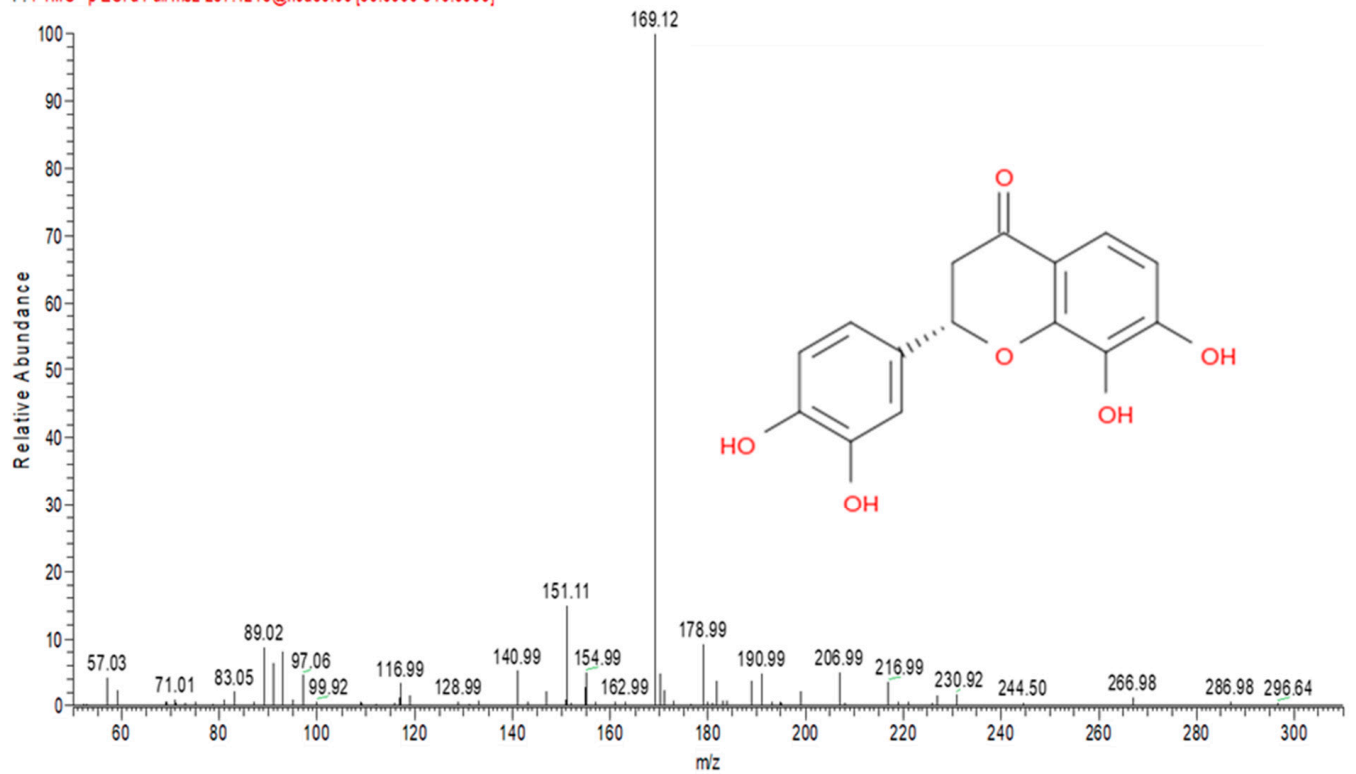

Figure 7. Isookanin. 


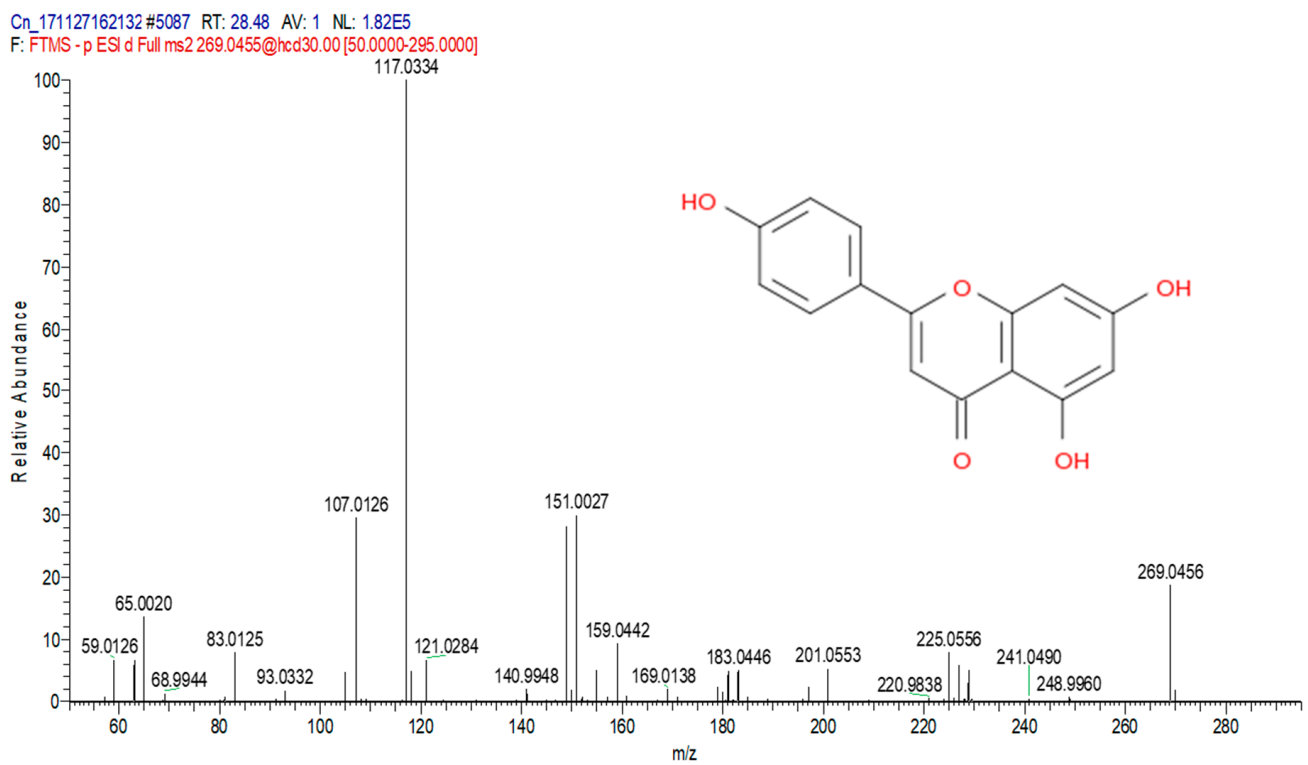

Figure 8. Apigenin.

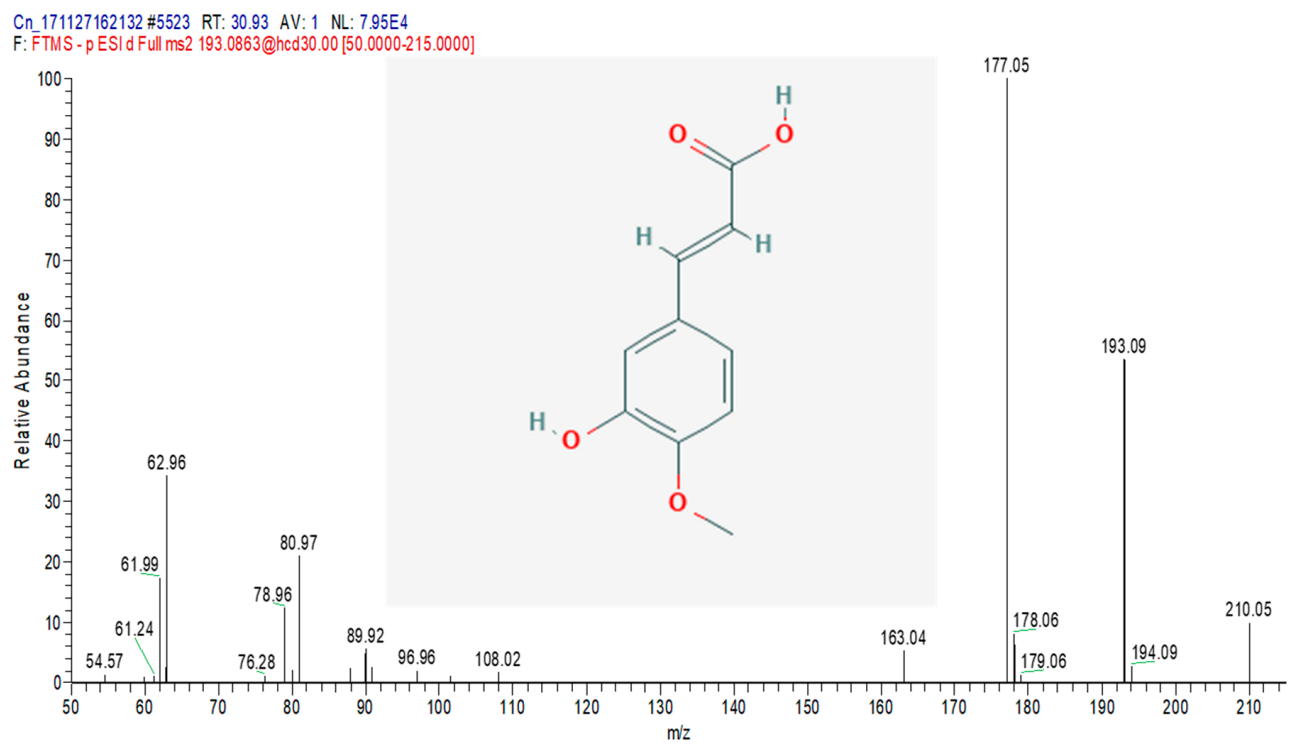

Figure 9. Ferulic acid.

\subsection{Acute Toxicity Study}

\subsubsection{Body Weight Gain}

The effects of oral administration of $2000 \mathrm{mg} / \mathrm{kg}$ CELE on the mean body weight gain of mice is presented on Figure 10. Repeated measures ANOVA with a Greenhouse-Geisser correction and Bonferroni post hoc test showed significant $(p<0.05)$ differences in the body weight gain of the treated mice across the 14 days experimental period. There was $267 \%$ decrease $(p>0.05)$ as well as $189 \%$ increase $(p<0.05)$ in the body weight gain of the mice in group B at weeks $1(-0.47 \pm 0.60 \mathrm{~g})$ and 2 $(0.83 \pm 0.64 \mathrm{~g})$ of the experiment, respectively, compared to group A at weeks $1(0.28 \pm 0.60 \mathrm{~g})$ and 2 $(0.29 \pm 0.21 \mathrm{~g})$ (Figure 10). 


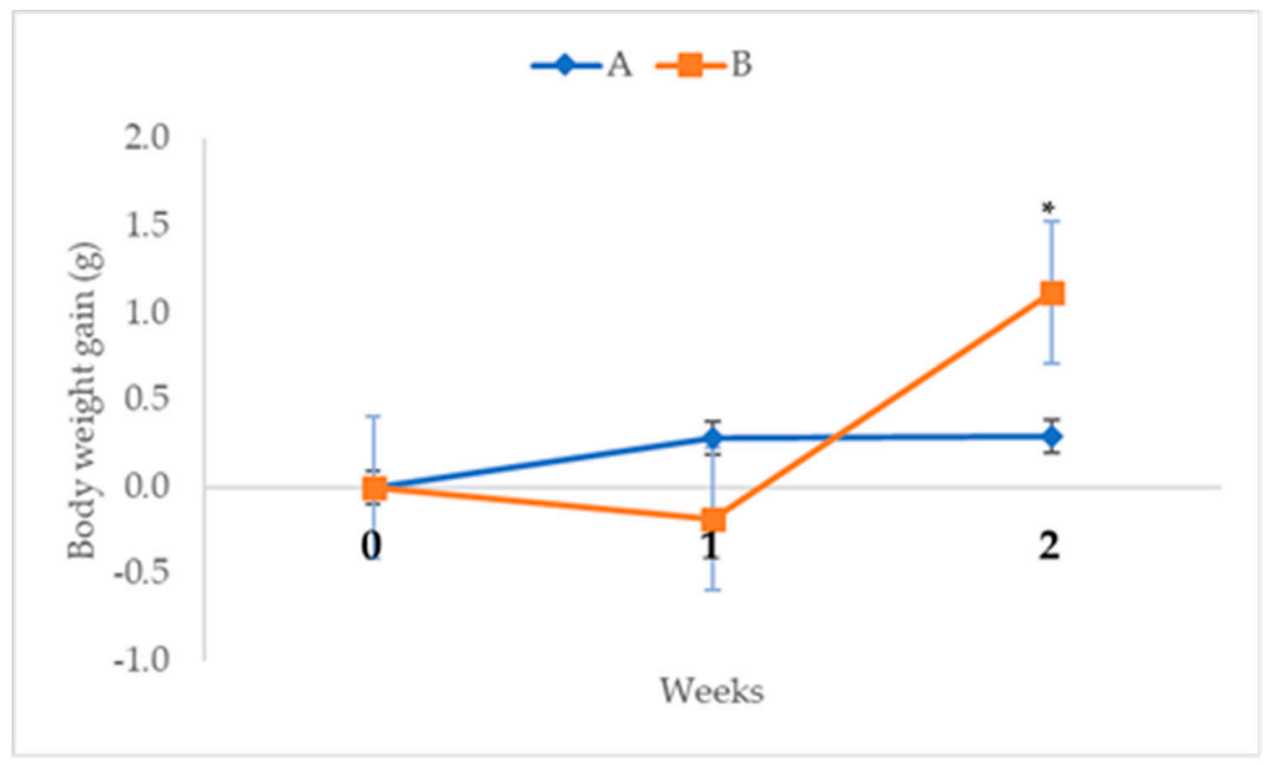

Figure 10. Weekly body weight gain ( $\mathrm{g}$ ) of female ICR mice in acute toxicity study of CELE. Key: $\mathrm{CELE}=$ Clinacanthus nutans ethanolic leaf extract, $\mathrm{A}=$ control, $\mathrm{B}=2000 \mathrm{mg} / \mathrm{kg}$ CELE, ${ }^{*}=$ significantly different at $p<0.05$.

\subsubsection{Relative Organs Weight}

The effects of oral administration of $2000 \mathrm{mg} / \mathrm{kg}$ CELE on the relative organ weight of female ICR mice are presented on Table 2 . There were no statistically significant $(p>0.05)$ differences between groups in the relative organs weights of the mice treated with CELE throughout the 14 days, as determined by Student's $t$ test (Table 2). The organ to body weight ratios of liver (5.70 \pm 0.33 ) was $6.3 \%$, which was higher $(p>0.05)$ in group B $(5.70 \pm 0.33)$ compared to A $(5.39 \pm 0.44)$, while the organ to body weight ratios of right kidney $(0.60 \pm 0.04)$, spleen $(0.57 \pm 0.05)$, heart $(0.62 \pm 0.10)$, and lungs $(1.07 \pm 0.14)$ were $15.49 \%, 3.39 \%, 4.62 \%$, and $28.19 \%$, which were lower $(p>0.05)$ in group B compared to the relative organs weights of right kidney $(0.71 \pm 0.08)$, spleen $(0.59 \pm 0.10)$, heart $(0.65 \pm 0.07)$ and lungs $(1.49 \pm 0.17)$ in group A. (Table 2).

Table 2. Relative organ weights in \% (mean \pm SEM) of female ICR mice in acute toxicity study of CELE.

\begin{tabular}{ccc}
\hline Organs & A & B \\
\hline Liver & $5.39 \pm 0.44$ & $5.70 \pm 0.33$ \\
Right Kidney & $0.71 \pm 0.08$ & $0.60 \pm 0.04$ \\
Left Kidney & $0.79 \pm 0.08$ & $0.81 \pm 0.10$ \\
Spleen & $0.59 \pm 0.10$ & $0.57 \pm 0.05$ \\
Heart & $0.65 \pm 0.07$ & $0.62 \pm 0.10$ \\
Lungs & $1.49 \pm 0.17$ & $1.07 \pm 0.14$ \\
Brain & $1.25 \pm 0.08$ & $1.21 \pm 0.04$ \\
Uterus & $1.95 \pm 0.31$ & $2.10 \pm 0.30$
\end{tabular}

Key: CELE = Clinacanthus nutans ethanolic leaf extract, A = Control, B $=2000 \mathrm{mg} / \mathrm{kg}$ CELE , the differences between groups A and B were not statistically significant $(p>0.05)$.

\subsubsection{Haematological Parameters}

The effects of oral administration of $2000 \mathrm{mg} / \mathrm{kg}$ CELE on the haematological parameters of female ICR mice is presented on Table 3. There were no statistically significant $(p>0.05)$ differences between groups in the haematological parameters of the mice treated with $2000 \mathrm{mg} / \mathrm{kg}$ CELE throughout the 14-day observation period, as determined by Student's $t$ test (Table 3). However, the haemoglobin concentration was $2.8 \%$ higher $(p>0.05)$ in group B $(181.80 \pm 5.70 \mathrm{~g} / \mathrm{L})$ compared to A $(176.80 \pm 2.87 \mathrm{~g} / \mathrm{L})$ 
and the values of the platelets were $4.4 \%$ lower $(p>0.05)$ in group B $\left(1252.00 \pm 204.80 \times 10^{9} / \mathrm{L}\right)$ compared to $\mathrm{A}\left(1308.40 \pm 32.66 \times 10^{9} / \mathrm{L}\right)$ (see Table 3$)$. Moreover, the values for the total white blood cell counts (TWBC), neutrophils, lymphocytes and monocytes between groups A and B were comparable $(p>0.05)$ (see Table 3).

Table 3. Haematological parameters (mean \pm SEM) of female ICR mice in acute toxicity study of CELE.

\begin{tabular}{ccc}
\hline Parameters & A & B \\
\hline Red Blood Cells $\left(\times 10^{12} / \mathrm{L}\right)$ & $11.00 \pm 0.12$ & $11.28 \pm 0.48$ \\
Haemoglobin $(\mathrm{g} / \mathrm{L})$ & $176.80 \pm 2.87$ & $181.80 \pm 5.70$ \\
PCV $(1 / \mathrm{l})$ & $0.38 \pm 0.01$ & $0.37 \pm 0.02$ \\
Platelets $\left(\times 10^{9} / \mathrm{L}\right)$ & $1308.40 \pm 32.66$ & $1252.00 \pm 204.80$ \\
MCV $(\mathrm{fl})$ & $62.40 \pm 0.51$ & $62.80 \pm 0.97$ \\
MCH $(\mathrm{pg})$ & $16.10 \pm 0.26$ & $16.14 \pm 0.37$ \\
MCHC $(\mathrm{g} / \mathrm{L})$ & $257.80 \pm 3.07$ & $257.20 \pm 3.89$ \\
Plasma Proteins $(\mathrm{g} / \mathrm{L})$ & $61.60 \pm 2.14$ & $61.60 \pm 3.54$ \\
White Blood Cells $\left(\times 10^{9} / \mathrm{L}\right)$ & $7.07 \pm 1.06$ & $7.16 \pm 0.86$ \\
Neutrophils $\left(\times 10^{9} / \mathrm{L}\right)$ & $1.51 \pm 0.46$ & $1.57 \pm 0.21$ \\
Lymphocytes $\left(\times 10^{9} / \mathrm{L}\right)$ & $5.08 \pm 0.64$ & $5.16 \pm 0.60$ \\
Monocytes $\left(\times 10^{9} / \mathrm{L}\right)$ & $0.40 \pm 0.07$ & $0.43 \pm 0.04$ \\
Eosinophils $\left(\times 10^{9} / \mathrm{L}\right)$ & $0.08 \pm 0.06$ & $0.00 \pm 0.00$ \\
Basophils $\left(\times 10^{9} / \mathrm{L}\right)$ & $0.00 \pm 0.00$ & $0.00 \pm 0.00$
\end{tabular}

Key: CELE = Clinacanthus nutans ethanolic leaf extract, $\mathrm{A}=\mathrm{C}$ Control, $\mathrm{B}=2000 \mathrm{mg} / \mathrm{kg}$ CELE, MCV = mean corpuscular volume, $\mathrm{MCH}=$ mean corpuscular haemoglobin, $\mathrm{MCHC}=$ mean corpuscular haemoglobin concentration.

\subsubsection{Biochemical Parameters}

The effects of oral administration of $2000 \mathrm{mg} / \mathrm{kg}$ CELE on the plasma biochemical parameters of ICR mice is presented on Table 4. The plasma level of creatinine was $17.04 \%$ lower $(p>0.05)$ in group B $(29.20 \pm 1.50 \mu \mathrm{mol} / \mathrm{L})$ compared to A $(35.20 \pm 2.42 \mu \mathrm{mol} / \mathrm{L})$. Furthermore, there was $185 \%$ significant $(p<0.05)$ increase in alanine aminotransferase (ALT) in group B $(289.60 \pm 30.99 \mathrm{U} / \mathrm{L})$ compared to A $(101.60 \pm 5.75 \mathrm{U} / \mathrm{L})$, a $101.5 \%$ significant $(p<0.05)$ increase in aspartate aminotransferase (AST) in group B $(344.60 \pm 45.92 \mathrm{U} / \mathrm{L})$ compared to A $(171.00 \pm 10.89 \mathrm{U} / \mathrm{L})$, as well as a $67.6 \%$ significant $(p<0.05)$ increase in creatinine kinase $(\mathrm{CK})$ in group B $(549.20 \pm 66.05 \mathrm{U} / \mathrm{L})$ compared to $\mathrm{A}(327.60 \pm 35.71 \mathrm{U} / \mathrm{L})$. The plasma level of total proteins was $5.82 \%$ lower $(p>0.05)$ in group B $(59.86 \pm 2.17 \mathrm{~g} / \mathrm{L})$ compared to A $(63.56 \pm 1.71 \mathrm{~g} / \mathrm{L})$. Moreover, the plasma albumin level was $6.2 \%$ lower $(p>0.05)$ in group B $(32.00 \pm 0.45 \mathrm{~g} / \mathrm{L})$ compared to A $(34.10 \pm 0.73 \mathrm{~g} / \mathrm{L})$ (see Table 4$)$.

Table 4. Biochemical parameters (mean \pm SEM) of female ICR mice in acute toxicity study of CELE.

\begin{tabular}{ccc}
\hline Parameters & A & B \\
\hline Urea $(\mathrm{mmol} / \mathrm{L})$ & $9.60 \pm 0.32$ & $9.24 \pm 0.66$ \\
Creatinine $(\mu \mathrm{mol} / \mathrm{L})$ & $35.20 \pm 2.42$ & $29.20 \pm 1.50$ \\
ALT $(\mathrm{U} / \mathrm{L})$ & $101.60 \pm 5.75$ & $289.60 \pm 30.99 *$ \\
AST $(\mathrm{U} / \mathrm{L})$ & $171.00 \pm 10.89$ & $344.60 \pm 45.92 *$ \\
CK $(\mathrm{U} / \mathrm{L})$ & $327.60 \pm 35.71$ & $549.20 \pm 66.05 *$ \\
Total Protein $(\mathrm{g} / \mathrm{L})$ & $63.56 \pm 1.71$ & $59.86 \pm 2.17$ \\
Albumin $(\mathrm{g} / \mathrm{L})$ & $34.10 \pm 0.73$ & $32.00 \pm 0.45$ \\
Globulins $(\mathrm{g} / \mathrm{L})$ & $29.60 \pm 1.21$ & $28.00 \pm 2.00$
\end{tabular}

Key: CELE = Clinacanthus nutans ethanolic leaf extract, $\mathrm{A}=$ Control, $\mathrm{B}=2000 \mathrm{mg} / \mathrm{kg}$ CELE, ALT $=$ alanine aminotransferase, AST = aspartate aminotransferase, $\mathrm{CK}=$ creatinine kinase; Values in the same row with asterisk differ significantly $(p<0.05)$. 


\subsubsection{Liver Lesion Scoring}

The effects of oral administration of $2000 \mathrm{mg} / \mathrm{kg}$ CELE on the histology of liver of female ICR mice are presented on Table 5. Mann-Whitney $U$ test revealed no statistically significant $(p>0.05)$ differences in the liver lesion score between the control and treatment groups (Table 5).

Table 5. Liver lesion scores (mean \pm SEM) for female ICR mice in acute toxicity study of CELE.

\begin{tabular}{ccc}
\hline Lesions & A & B \\
\hline Hydropic degeneration & $0.50 \pm 0.32$ & $1.20 \pm 0.37$ \\
Eosinophilic cytoplasm & $0.20 \pm 0.24$ & $0.60 \pm 0.20$ \\
Pyknosis & $0.30 \pm 0.30$ & $0.50 \pm 0.32$ \\
Karyolysis & $0.00 \pm 0.00$ & $0.00 \pm 0.00$ \\
Sinusoidal dilatation & $0.40 \pm 0.24$ & $0.60 \pm 0.24$ \\
Activated Kupffer cells & $0.20 \pm 0.20$ & $0.20 \pm 0.20$ \\
Inflammation & $0.00 \pm 0.00$ & $0.00 \pm 0.00$ \\
Regeneration & $0.50 \pm 0.32$ & $0.70 \pm 0.44$ \\
Key: CELE = Clinacanthus nutans ethanolic leaf extract, A = Control, B = 2000 mg/kg CELE.
\end{tabular}

\subsubsection{Kidney Lesion Scoring}

The effects of oral administration of $2000 \mathrm{mg} / \mathrm{kg}$ CELE on the histology of kidneys of female ICR mice are presented on Table 6. There were no statistically significant $(p>0.05)$ differences in the kidney lesion score between the control and treatment groups as shown by Mann-Whitney U test (Table 6).

Table 6. Kidney lesion scores (mean \pm SEM) for female ICR mice in acute toxicity study of CELE.

\begin{tabular}{ccc}
\hline Lesions & A & B \\
\hline Hydropic degeneration & $0.00 \pm 0.00$ & $0.00 \pm 0.00$ \\
Eosinophilic cytoplasm & $0.00 \pm 0.00$ & $0.20 \pm 0.20$ \\
Pyknosis & $0.00 \pm 0.00$ & $0.00 \pm 0.00$ \\
Karyolysis & $0.00 \pm 0.00$ & $0.00 \pm 0.00$ \\
Nephritis & $0.00 \pm 0.00$ & $0.20 \pm 0.20$ \\
Protein casts & $0.00 \pm 0.00$ & $0.00 \pm 0.00$ \\
Cellular Casts & $0.00 \pm 0.00$ & $0.00 \pm 0.00$ \\
Granular Casts & $0.00 \pm 0.00$ & $0.00 \pm 0.00$ \\
\hline
\end{tabular}

Key: CELE = Clinacanthus nutans ethanolic leaf extract, $\mathrm{A}=$ Control, $\mathrm{B}=2000 \mathrm{mg} / \mathrm{kg}$ CELE.

\subsection{Subacute Toxicity Study}

\subsubsection{Body Weight Gain}

The effects of repeated oral administration of different doses of CELE daily for 28 days on the average body weight gain of female ICR mice are presented on Figure 11. Repeated measures ANOVA with a Greenhouse-Geisser correction and Bonferroni post hoc test showed significant $(p<0.05)$ differences in the body weight gain of the treated mice across the 4-week experimental period (Figure 11). There was $136.21 \%$ increased $(p>0.05)$ weight gain in group B at week $1(0.55 \pm 0.98 \mathrm{~g})$, as well as $121.14 \%, 57.78 \%$ and $127.81 \%$ reductions in the body weight gains of the mice in group $B$ at weeks $2(-0.07 \pm 0.43 ; p>0.05), 3(0.70 \pm 0.61 ; p<0.05)$ and $4(-0.38 \pm 0.34 ; p<0.05)$ of the experiment, respectively, compared to group A at weeks $1(0.23 \pm 0.36 \mathrm{~g}), 2(0.35 \pm 0.31 \mathrm{~g}), 3(1.66 \pm 0.24 \mathrm{~g})$ and 4 $(1.35 \pm 0.54 \mathrm{~g})$ (Figure 11). Furthermore, there was $133.62 \%$ increase in the body weight gain in group C, at week $1(0.54 \pm 0.83 \mathrm{~g} ; p>0.05)$ of the experiment, as well as $360 \%$ and $142.16 \%$ reductions in the average body weight gains in group $C$ at weeks $2(-0.91 \pm 0.85 \mathrm{~g} ; p<0.05)$ and $4(-0.57 \pm 0.26 \mathrm{~g}$; $p<0.05$ ) of the experiment respectively, compared to group A at weeks 1, 2 and 4 (see Figure 11). Similarly, the average body weight gain of the mice in group D were $838.79 \%, 40.57 \%$ and $175 \%$ lower at weeks $1(-1.71 \pm 1.54 \mathrm{~g} ; p<0.05), 2(0.21 \pm 0.75 \mathrm{~g} ; p>0.05)$ and $4(-1.01 \pm 1.29 \mathrm{~g} ; p<0.05)$ of the 
experiment, respectively, compared to group A at weeks 1, 2 and 4 (see Figure 11). Correspondingly, there were $142.24 \%, 220 \%, 85.16 \%$ and $102.96 \%$ reductions in the body weight gains of the mice in group E at weeks $1(-0.10 \pm 0.45 \mathrm{~g} ; p>0.05), 2(-0.42 \pm 0.66 \mathrm{~g} ; p>0.05), 3(0.25 \pm 0.40 \mathrm{~g} ; p<0.05)$ and 4 $(-0.04 \pm 0.28 \mathrm{~g} ; p<0.05)$ of the experiment, respectively, compared to group A at weeks $1,2,3$ and 4 (see Figure 11).

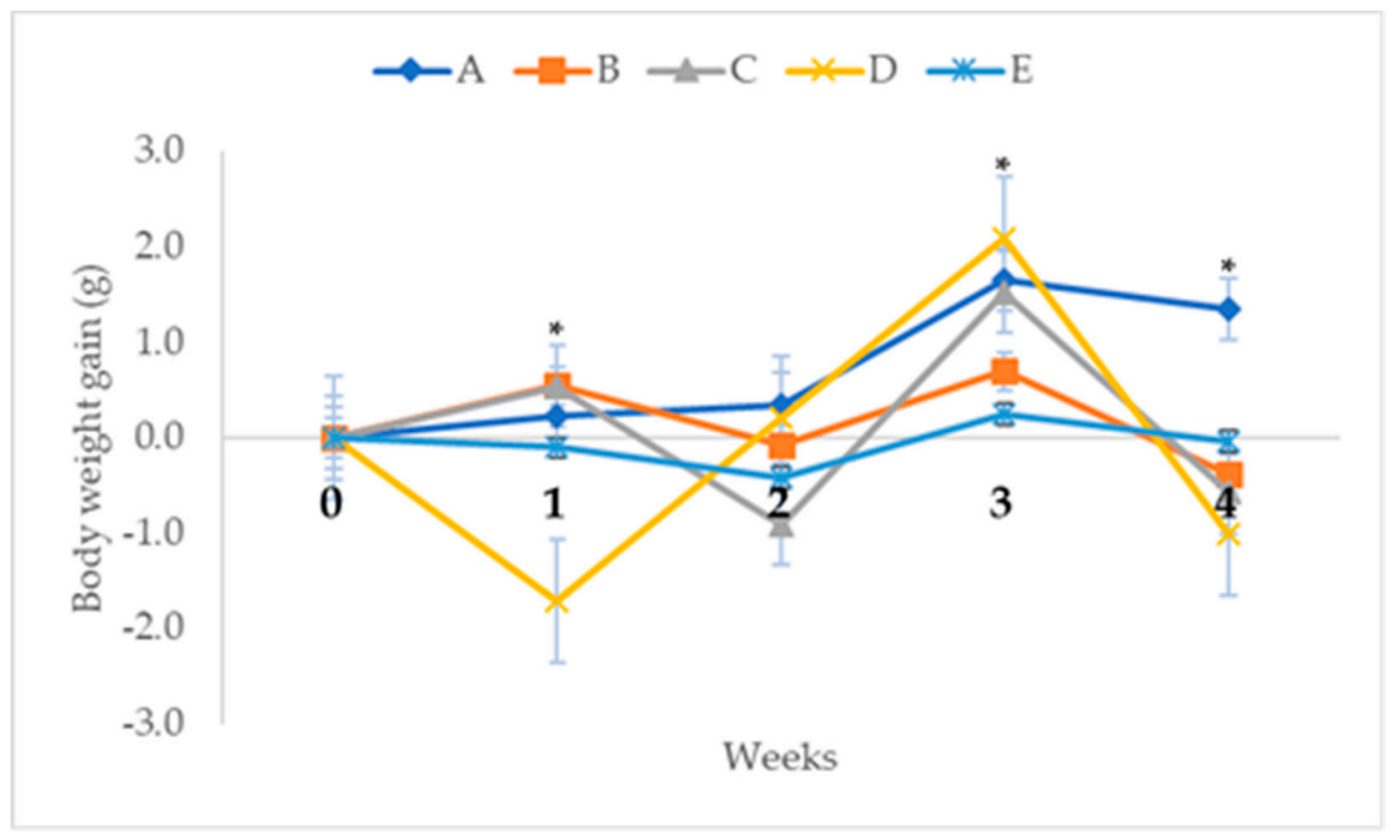

Figure 11. Average (mean \pm SEM) weekly body weight gain $(\mathrm{g})$ of female ICR mice in subacute toxicity study of CELE. Key: A = control, B = $125 \mathrm{mg} / \mathrm{kg}$ CELE, C $=250 \mathrm{mg} / \mathrm{kg} \mathrm{CELE,} \mathrm{D} \mathrm{=} 500 \mathrm{mg} / \mathrm{kg}$ $\mathrm{CELE}, \mathrm{E}=1000 \mathrm{mg} / \mathrm{kg}$ CELE, * significantly different at $p<0.05, \mathrm{SEM}=$ standard error of mean, CELE $=$ Clinacanthus nutans ethanolic leaf extract.

\subsubsection{Relative Organs Weight}

The effects of repeated oral administration of different doses of CELE daily for 28 days on the relative organs weight of female ICR mice are presented on Table 7 . There were no statistically significant $(p>0.05)$ differences between groups in the relative organ weights of the mice treated with CELE daily for 28 days, as determined by one-way ANOVA, except for the uterus (Table 7). However, the relative weights of liver were $18.5 \%, 18.8 \%$ and $14 \%$ lower $(p>0.05 ; \mathrm{F}=0.964)$ in groups $\mathrm{B}(5.55 \pm 0.38), \mathrm{C}(5.53 \pm 0.34)$ and $\mathrm{E}(5.86 \pm 0.41)$, respectively, compared to A $(6.81 \pm 0.85)$. The relative weights of kidney were $2.5 \%$ and $8.9 \%$ higher $(p>0.05 ; \mathrm{F}=0.651)$ in groups $\mathrm{D}(0.81 \pm 0.05)$ and $\mathrm{E}$ $(0.86 \pm 0.13)$, respectively, compared to A $(0.79 \pm 0.11)$ (see Table 7$)$. The relative organ weight of uterus were $16.6 \%, 37.9 \%, 39.1 \%$ and $15.3 \%$ lower $(p<0.05 ; \mathrm{F}=1.487)$ in groups B $(1.96 \pm 0.26), \mathrm{C}(1.46 \pm 0.29)$, $\mathrm{D}(1.43 \pm 0.15)$ and $\mathrm{E}(1.99 \pm 0.37)$, respectively, compared to group A (2.35 \pm 0.25$)$ (see Table 7).

\subsubsection{Haematological Parameters}

The effects of repeated oral administration of different doses of CELE daily for 28 days on the haematological parameters of female ICR mice is presented on Table 8. There were statistically significant $(p<0.05)$ differences in the haematological parameters between groups as determined by one-way ANOVA. The Tukey post hoc test showed that the mice treated with CELE had 3\% and 9.3\% significant $(p<0.05)$ increases in the values of $\mathrm{MCV}$ and $\mathrm{MCH}$, respectively, in group $\mathrm{B}$ $(68.25 \pm 1.80 \mathrm{fl} ; 17.33 \pm 0.56 \mathrm{pg})$ compared to A $(65.80 \pm 0.97 \mathrm{fl} ; 15.86 \pm 0.28 \mathrm{pg})$. There were also $5.5 \%$ and $7.3 \%$ significant decreases $(p<0.05)$ in the values of MCV in groups D $(62.20 \pm 1.69 \mathrm{fl})$ and $\mathrm{E}$ $(61.00 \pm 1.48 \mathrm{fl})$, respectively, compared to A. Moreover, the values of MCH in groups D $(15.14 \pm 0.55 \mathrm{pg})$ 
and E $(15.10 \pm 0.36 \mathrm{pg})$ were $4.5 \%$ and $4.8 \%$ significantly $(p<0.05)$ lower, respectively, compared to A. The haemoglobin concentrations were $3.9 \%, 7.4 \%, 12 \%$ and $6.5 \%$ lower $(p>0.05 ; \mathrm{F}=2.692)$ in groups B $(169.50 \pm 3.75 \mathrm{~g} / \mathrm{L}), \mathrm{C}(163.40 \pm 2.18 \mathrm{~g} / \mathrm{L}), \mathrm{D}(155.20 \pm 4.66 \mathrm{~g} / \mathrm{L})$ and $\mathrm{E}(165.00 \pm 4.54 \mathrm{~g} / \mathrm{L})$, respectively, compared to A $(176.40 \pm 8.35 \mathrm{~g} / \mathrm{L})$ (see Table 8$)$. Besides, there was $59.8 \%$ significant $(p<0.05 ; \mathrm{F}=4.014)$ increase in total leukocyte counts in group C $\left(11.86 \pm 1.00 \times 10^{9} / \mathrm{L}\right)$ compared to A $\left(7.42 \pm 0.95 \times 10^{9} / \mathrm{L}\right)$. The increased leukocyte counts were accompanied by $102.8 \%$ significant $(p<0.05$; $\mathrm{F}=2.961)$ increase in neutrophils in group $\mathrm{C}\left(3.61 \pm 0.88 \times 10^{9} / \mathrm{L}\right)$ compared to $\mathrm{A}\left(1.78 \pm 0.35 \times 10^{9} / \mathrm{L}\right)$, as well as $55.3 \%$ increase $(p>0.05 ; \mathrm{F}=2.677)$ in monocytes in group $\mathrm{C}\left(0.73 \pm 0.11 \times 10^{9} / \mathrm{L}\right)$ compared to $\mathrm{A}\left(0.47 \pm 0.09 \times 10^{9} / \mathrm{L}\right)$ (Table 8$)$.

Table 7. Relative organ weights in \% (mean \pm SEM) of female ICR mice in subacute toxicity study of CELE.

\begin{tabular}{cccccc}
\hline Organs (\%) & A & B & C & D & E \\
\hline Liver & $6.81 \pm 0.85$ & $5.55 \pm 0.38$ & $5.53 \pm 0.34$ & $6.17 \pm 0.54$ & $5.86 \pm 0.41$ \\
Right Kidney & $0.79 \pm 0.11$ & $0.76 \pm 0.09$ & $0.79 \pm 0.05$ & $0.81 \pm 0.05$ & $0.86 \pm 0.13$ \\
Left Kidney & $0.75 \pm 0.13$ & $0.78 \pm 0.09$ & $0.78 \pm 0.04$ & $0.89 \pm 0.09$ & $0.81 \pm 0.10$ \\
Spleen & $0.67 \pm 0.20$ & $0.40 \pm 0.02$ & $0.69 \pm 0.13$ & $0.79 \pm 0.16$ & $0.56 \pm 0.04$ \\
Heart & $0.59 \pm 0.09$ & $0.56 \pm 0.03$ & $0.55 \pm 0.04$ & $0.52 \pm 0.05$ & $0.56 \pm 0.03$ \\
Lungs & $1.22 \pm 0.21$ & $1.02 \pm 0.10$ & $1.11 \pm 0.08$ & $1.29 \pm 0.19$ & $1.30 \pm 0.08$ \\
Brain & $1.64 \pm 0.17$ & $1.48 \pm 0.10$ & $1.58 \pm 0.03$ & $1.61 \pm 0.08$ & $1.63 \pm 0.10$ \\
Uterus & $2.35 \pm 0.25$ & $1.96 \pm 0.26^{*}$ & $1.46 \pm 0.29 *$ & $1.43 \pm 0.15^{*}$ & $1.99 \pm 0.37^{*}$ \\
\hline
\end{tabular}

Key: CELE = Clinacanthus nutans ethanolic leaf extract, $\mathrm{A}=$ control, $\mathrm{B}=125 \mathrm{mg} / \mathrm{kg}$ CELE, C $=250 \mathrm{mg} / \mathrm{kg}$ CELE, $\mathrm{D}=500 \mathrm{mg} / \mathrm{kg}$ CELE, $\mathrm{E}=1000 \mathrm{mg} / \mathrm{kg}$ CELE, values in the same row with asterisk are significantly different at $p<0.05$.

Table 8. Haematological parameters (mean \pm SEM) of female ICR mice in subacute toxicity study of CELE.

\begin{tabular}{cccccc}
\hline Parameters & A & B & C & D & E \\
\hline $\mathrm{RBC}\left(\times 10^{12} / \mathrm{L}\right)$ & $11.15 \pm 0.65$ & $9.84 \pm 0.38$ & $10.29 \pm 0.28$ & $10.26 \pm 0.18$ & $10.99 \pm 0.38$ \\
$\mathrm{Hb}(\mathrm{g} / \mathrm{L})$ & $176.40 \pm 8.35$ & $169.50 \pm 3.75$ & $163.40 \pm 2.18$ & $155.20 \pm 4.66$ & $165.00 \pm 4.54$ \\
$\mathrm{PCV}(\mathrm{l} / \mathrm{l})$ & $0.48 \pm 0.03$ & $0.44 \pm 0.02$ & $0.39 \pm 0.02$ & $0.41 \pm 0.03$ & $0.43 \pm 0.01$ \\
Platelets $\left(\times 10^{9} / \mathrm{L}\right)$ & $989.80 \pm 197.4$ & $891.50 \pm 205.0$ & $995.60 \pm 224.3$ & $1280.40 \pm 126$. & $860.20 \pm 195.2$ \\
$\mathrm{MCV}(\mathrm{fl})$ & $65.80 \pm 0.97$ & $68.25 \pm 1.80^{*}$ & $63.80 \pm 1.36$ & $62.20 \pm 1.69$ & $61.00 \pm 1.48^{*}$ \\
$\mathrm{MCH}(\mathrm{pg})$ & $15.86 \pm 0.28$ & $17.33 \pm 0.56^{*}$ & $15.92 \pm 0.43$ & $15.14 \pm 0.55^{*}$ & $15.10 \pm 0.36$ \\
$\mathrm{MCHC}(\mathrm{g} / \mathrm{L})$ & $241.80 \pm 3.54$ & $248.50 \pm 4.03$ & $248.80 \pm 2.75$ & $243.00 \pm 4.32$ & $255.20 \pm 3.02$ \\
$\mathrm{PP}(\mathrm{g} / \mathrm{L})$ & $72.00 \pm 2.00$ & $73.00 \pm 2.05$ & $79.40 \pm 6.66$ & $77.40 \pm 5.12$ & $72.00 \pm 1.67$ \\
$\mathrm{WBC}\left(\times 10^{9} / \mathrm{L}\right)$ & $7.42 \pm 0.95$ & $9.18 \pm 1.03$ & $11.86 \pm 1.00 *$ & $8.16 \pm 0.50$ & $9.47 \pm 0.56$ \\
$\mathrm{Neutrophils}\left(\times 10^{9} / \mathrm{L}\right)$ & $1.78 \pm 0.35$ & $1.60 \pm 0.22$ & $3.61 \pm 0.88 *$ & $2.57 \pm 0.25$ & $2.85 \pm 0.34$ \\
Lymphocytes $\left(\times 10^{9} / \mathrm{L}\right)$ & $5.14 \pm 0.76$ & $7.14 \pm 0.81$ & $7.48 \pm 0.97$ & $4.98 \pm 0.76$ & $6.41 \pm 0.40$ \\
Monocytes $\left(\times 10^{9} / \mathrm{L}\right)$ & $0.47 \pm 0.09$ & $0.42 \pm 0.05$ & $0.73 \pm 0.11$ & $0.56 \pm 0.04$ & $0.51 \pm 0.06$ \\
Eosinophils $\left(\times 10^{9} / \mathrm{L}\right)$ & $0.03 \pm 0.03$ & $0.02 \pm 0.02$ & $0.04 \pm 0.04$ & $0.05 \pm 0.05$ & $0.06 \pm 0.04$ \\
Basophils $\left(\times 10^{9} / \mathrm{L}\right)$ & $0.00 \pm 0.00$ & $0.00 \pm 0.00$ & $0.00 \pm 0.00$ & $0.00 \pm 0.00$ & $0.00 \pm 0.00$ \\
\hline
\end{tabular}

Key: CELE = Clinacanthus nutans ethanolic leaf extract, A = control, B $=125 \mathrm{mg} / \mathrm{kg}$ CELE, C $=250 \mathrm{mg} / \mathrm{kg}$ CELE, $\mathrm{D}=500 \mathrm{mg} / \mathrm{kg}$ CELE, $\mathrm{E}=1000 \mathrm{mg} / \mathrm{kg}$ CELE, values in the same row with asterisk were significantly different from the control group $(p<0.05), \mathrm{RBC}=$ red blood cells, $\mathrm{Hb}=$ haemoglobin, $\mathrm{PCV}=$ packed cell volume, $\mathrm{PP}=$ plasma protein, $\mathrm{WBC}=$ white blood cells, $\mathrm{MCV}=$ mean corpuscular volume, $\mathrm{MCH}=$ mean corpuscular haemoglobin, $\mathrm{MCHC}=$ mean corpuscular haemoglobin concentration .

\subsubsection{Plasma Biochemical Parameters}

The effects of repeated oral administration of different doses of CELE daily for 28 days on the plasma biochemical parameters of female ICR mice is presented on Table 9. There were statistically significant $(p<0.05)$ differences between groups in the plasma biochemical parameters of the mice as determined by one-way ANOVA (Table 9). The Tukey post hoc test showed that the mice treated with CELE had $77.7 \%$ significant $(p<0.05 ; \mathrm{F}=4.118)$ increase in creatinine level in group $\mathrm{E}$ 
$(33.40 \pm 2.93 \mu \mathrm{mol} / \mathrm{L})$ compared to A $(18.80 \pm 1.62 \mu \mathrm{mol} / \mathrm{L})$. However, the urea levels were $10.03 \%$ and $27.4 \%$ lower in groups $C(10.31 \pm 1.24 \mathrm{mmol} / \mathrm{L} ; p>0.05 ; \mathrm{F}=1.113)$ and $\mathrm{E}(8.45 \pm 0.60 \mathrm{mmol} / \mathrm{L}$; $p<0.05)$, respectively, compared to group A $(11.64 \pm 0.94 \mathrm{mmol} / \mathrm{L})$. Furthermore, there was also $105.7 \%$ significant $(p<0.05 ; \mathrm{F}=4.063)$ increase in the plasma level of ALT in group D $(265.80 \pm 45.03 \mathrm{U} / \mathrm{L})$ compared to A $(129.20 \pm 15.81 \mathrm{U} / \mathrm{L})$. The plasma levels of AST were $13.1 \%$ and $4.8 \%$ higher $(p>0.05$; $\mathrm{F}=0.978)$ in groups $\mathrm{C}(421.87 \pm 11.07 \mathrm{U} / \mathrm{L})$ and $\mathrm{E}(390.90 \pm 29.34 \mathrm{U} / \mathrm{L})$, respectively, compared to group A ( $373.00 \pm 8.93 \mathrm{U} / \mathrm{L})$ (Table 9$)$. In addition, the plasma levels of total proteins were $5.9 \%$ and $3.83 \%$ higher $(p>0.05 ; \mathrm{F}=0.625)$ in groups $\mathrm{D}(67.98 \pm 4.32 \mathrm{~g} / \mathrm{L})$ and $\mathrm{E}(66.68 \pm 1.51 \mathrm{~g} / \mathrm{L})$, respectively, compared to group A $(64.22 \pm 1.78 \mathrm{~g} / \mathrm{L})$. The plasma albumin was $9.70 \%$ lower $(p>0.05 ; \mathrm{F}=0.457)$ in group E $(29.13 \pm 4.05 \mathrm{~g} / \mathrm{L})$, compared to A $(32.26 \pm 1.25 \mathrm{~g} / \mathrm{L})$. However, there were $15.3 \%$ and $17.5 \%$ increases $(p>0.05 ; \mathrm{F}=0.927)$ in the plasma levels of globulins in groups $\mathrm{D}(36.84 \pm 3.74 \mathrm{~g} / \mathrm{L})$ and $\mathrm{E}$ $(37.55 \pm 5.17 \mathrm{~g} / \mathrm{L})$, respectively, compared to group A $(31.96 \pm 2.06 \mathrm{~g} / \mathrm{L})($ Table 9$)$.

Table 9. Biochemical parameters (mean \pm SEM) of female ICR mice in subacute toxicity study of CELE.

\begin{tabular}{cccccc}
\hline Parameters & A & B & C & D & E \\
\hline Urea $(\mathrm{mmol} / \mathrm{L})$ & $11.64 \pm 0.94$ & $10.98 \pm 1.20$ & $10.31 \pm 1.24$ & $11.06 \pm 1.61$ & $8.45 \pm 0.60^{*}$ \\
Creatinine $(\mu \mathrm{mol} / \mathrm{L})$ & $18.80 \pm 1.62$ & $19.40 \pm 3.23$ & $24.40 \pm 3.54$ & $24.80 \pm 2.73$ & $33.40 \pm 2.93 *$ \\
ALT (U/L) & $129.20 \pm 15.81$ & $185.53 \pm 24.26$ & $209.53 \pm 11.44$ & $265.80 \pm 45.0 *$ & $173.10 \pm 10.38$ \\
AST (U/L) & $373.00 \pm 8.93$ & $362.67 \pm 34.42$ & $421.87 \pm 11.07$ & $362.60 \pm 30.78$ & $390.90 \pm 29.34$ \\
CK (U/L) & $627.20 \pm 20.53$ & $647.20 \pm 95.80$ & $634.27 \pm 32.34$ & $625.20 \pm 99.88$ & $592.80 \pm 121.3$ \\
Total Protein (g/L) & $64.22 \pm 1.78$ & $63.83 \pm 1.91$ & $63.87 \pm 1.10$ & $67.98 \pm 4.32$ & $66.68 \pm 1.51$ \\
Albumin (g/L) & $32.26 \pm 1.25$ & $32.56 \pm 0.94$ & $31.52 \pm 0.65$ & $31.14 \pm 0.81$ & $29.13 \pm 4.05$ \\
Globulins (g/L) & $31.96 \pm 2.06$ & $31.27 \pm 1.15$ & $32.11 \pm 1.43$ & $36.84 \pm 3.74$ & $37.55 \pm 5.17$ \\
\hline
\end{tabular}

Key: CELE = Clinacanthus nutans ethanolic leaf extract, A = control, B $=125 \mathrm{mg} / \mathrm{kg}$ CELE, C $=250 \mathrm{mg} / \mathrm{kg}$ CELE, $\mathrm{D}=500 \mathrm{mg} / \mathrm{kg}$ CELE, $\mathrm{E}=1000 \mathrm{mg} / \mathrm{kg}$ CELE, ALT = alanine aminotransferase, AST = aspartate aminotransferase, $\mathrm{CK}=$ creatinine kinase, values in the same row with asterisk differ significantly $(p<0.05)$.

\subsubsection{Liver Lesion Scoring}

The effects of repeated oral administration of different doses of CELE daily for 28 days on the histology of liver of female ICR mice is presented on Table 10. Kruskal-Wallis H test showed statistically significant $(p<0.05)$ differences in the lesion score between the different treatment groups (Table 10). Pairwise comparisons test revealed a mild activated Kupffer cells (Figure 12D,E), moderate sinusoidal dilatation and eosinophilic cytoplasm (Figure 12C) as well as mild pyknosis of the hepatocytes (Figure 12C,F). These were significantly $(p<0.05)$ higher in group E compared to A (Table 10). These findings corroborate those of plasma biochemical parameters, where there were statistically significant $(p<0.05)$ differences in the liver parameters between the control and treatment groups (Table 9).

Table 10. Liver lesion scores (mean \pm SEM) for female ICR mice in subacute toxicity study of CELE.

\begin{tabular}{cccccc}
\hline Lesions & A & B & C & D & E \\
\hline Hydropic Degeneration & $0.30 \pm 0.30$ & $0.60 \pm 0.24$ & $0.80 \pm 0.34$ & $0.80 \pm 0.37$ & $0.90 \pm 0.56$ \\
Eosinophilic Cytoplasm & $0.00 \pm 0.00$ & $0.40 \pm 0.24$ & $0.50 \pm 0.32$ & $1.00 \pm 0.42$ & $2.00 \pm 0.22 *$ \\
Pyknosis & $0.00 \pm 0.00$ & $0.30 \pm 0.30$ & $0.30 \pm 0.30$ & $1.40 \pm 0.40$ & $1.90 \pm 0.29 *$ \\
Karyolysis & $0.00 \pm 0.00$ & $0.00 \pm 0.00$ & $0.00 \pm 0.00$ & $0.00 \pm 0.00$ & $0.50 \pm 0.50$ \\
Sinusoidal Dilatation & $0.00 \pm 0.00$ & $1.10 \pm 0.33$ & $1.80 \pm 0.20$ & $2.30 \pm 0.12 *$ & $2.30 \pm 0.12^{*}$ \\
Activated Kupffer Cells & $0.00 \pm 0.00$ & $0.30 \pm 0.30$ & $1.10 \pm 0.33$ & $1.00 \pm 0.47$ & $1.70 \pm 0.20^{*}$ \\
Inflammation & $0.00 \pm 0.00$ & $0.20 \pm 0.20$ & $0.60 \pm 0.40$ & $0.50 \pm 0.32$ & $0.40 \pm 0.24$ \\
Regeneration & $1.10 \pm 0.46$ & $0.50 \pm 0.50$ & $0.20 \pm 0.20$ & $0.80 \pm 0.34$ & $0.80 \pm 0.34$ \\
\hline
\end{tabular}

Key: CELE = Clinacanthus nutans ethanolic leaf extract, $\mathrm{A}=$ control, $\mathrm{B}=125 \mathrm{mg} / \mathrm{kg}$ CELE, $\mathrm{C}=250 \mathrm{mg} / \mathrm{kg}$ CELE, $\mathrm{D}=500 \mathrm{mg} / \mathrm{kg}$ CELE, $\mathrm{E}=1000 \mathrm{mg} / \mathrm{kg}$ CELE , asterisk means statistical difference regarding group A (control). 

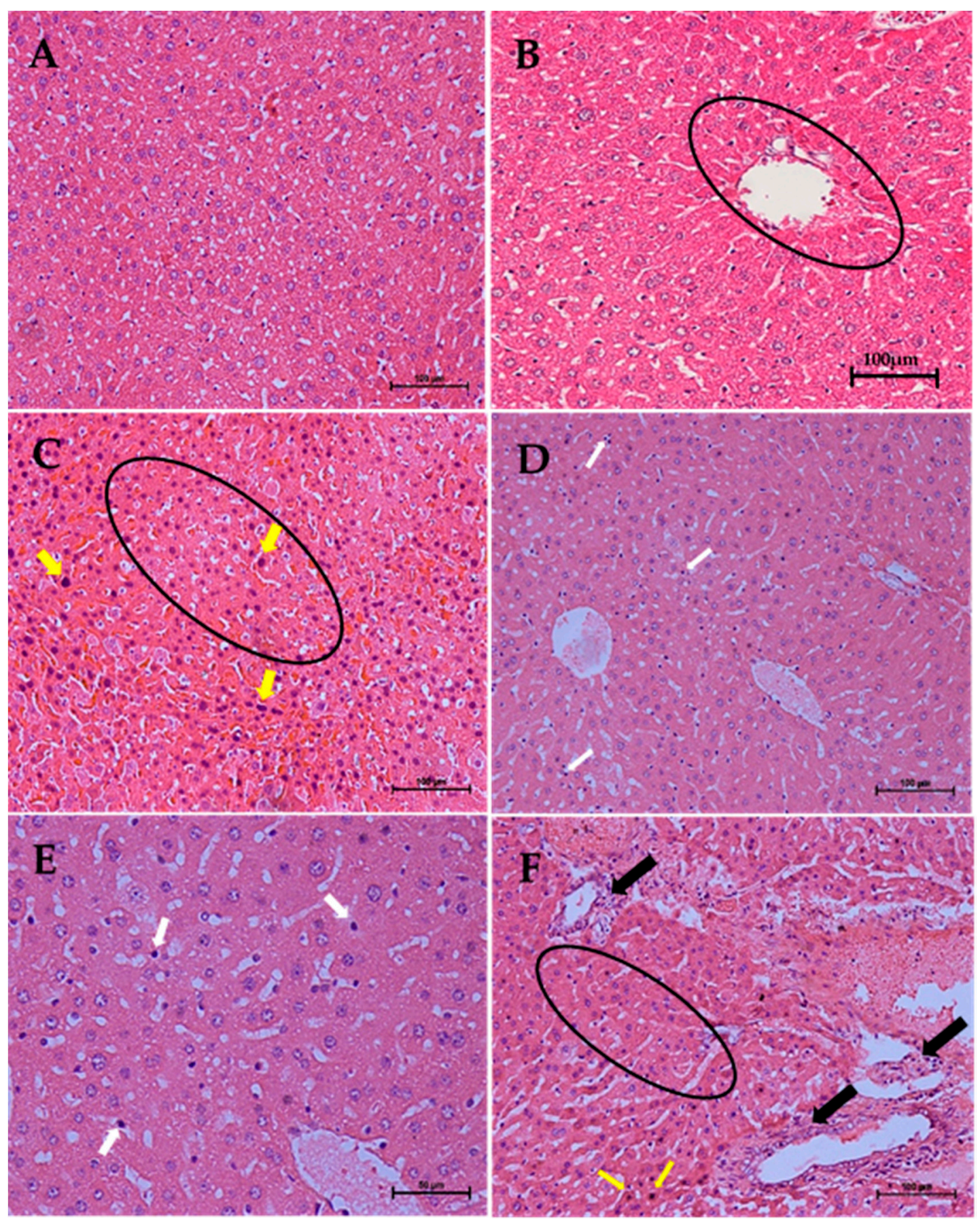

Figure 12. Effects of repeated oral administration of CELE for 28 days on the histology of liver of female ICR mice. Key: (A) Photomicrograph of a liver section (H\&E stain $\times 200)$ from a mouse in group A (control) showing normal architecture of liver. (B) Photomicrograph of a liver section (H and E stain $\times 200$ ) from a mouse in group A showing portal triad (encircled). (C) Photomicrograph of a liver section $(H \& E$ stain $\times 200)$ from a mouse in group E $(1000 \mathrm{mg} / \mathrm{kg}$ CELE) showing eosinophilic cytoplasm (encircled) and pyknotic nuclei (yellow arrows) of the hepatocytes. (D) Photomicrograph of a liver section $(\mathrm{H} \& \mathrm{E} \times 200)$ from a mouse in group $\mathrm{E}(1000 \mathrm{mg} / \mathrm{kg})$ showing activated Kupffer cells (white arrows). (E) Higher magnification (H and E stain $\times 400)$ of D showing activation of Kupffer cells (white arrows). (F) Photomicrograph of a liver section $(\mathrm{H}$ and $\mathrm{E}$ stain $\times 200)$ from a mouse in group $\mathrm{E}$ (1000 mg/kg CELE), showing hepatitis (black arrows), eosinophilic cytoplasm (encircled) and pyknosis (yellow arrows) of the hepatocytes, $\mathrm{H}$ and $\mathrm{E}=$ haematoxylin and eosin, $\mathrm{CELE}=$ Clinacanthus nutans ethanolic leaf extract. Scale bars represent $100 \mu \mathrm{m}$. 


\subsubsection{Kidney Lesion Scoring}

The effects of repeated oral administration of different doses of CELE daily for 28 days on the histology of kidneys of female ICR mice are presented on Table 11. Kruskal-Wallis H test showed statistically significant $(p<0.05)$ differences in the lesion score between the different treatment groups (Table 11). Pairwise comparisons test revealed a moderate to severe renal tubular necrosis characterised by eosinophilic cytoplasm and pyknosis of the renal tubular cells (Figure 13D) in group E (2.10 \pm 0.29$)$ compared A $(0.20 \pm 0.20)$. Furthermore, there was significant $(p<0.05)$ mild nephritis (Figure 13C,D) in group $\mathrm{E}(1.30 \pm 0.34)$ compared to $\mathrm{A}(0.00 \pm 0.00)$. (Table 11$)$.

Table 11. Kidney lesion scores (mean \pm SEM) for female ICR mice in subacute toxicity study of CELE.

\begin{tabular}{cccccc}
\hline Lesions & A & B & C & D & E \\
\hline Hydropic Degeneration & $0.00 \pm 0.00$ & $0.00 \pm 0.00$ & $0.00 \pm 0.00$ & $0.20 \pm 0.20$ & $0.40 \pm 0.24$ \\
Eosinophilic Cytoplasm & $0.20 \pm 0.20$ & $0.20 \pm 0.20$ & $0.20 \pm 0.20$ & $1.40 \pm 0.19$ & $2.1 \pm 0.29^{*}$ \\
Pyknosis & $0.00 \pm 0.00$ & $0.00 \pm 0.00$ & $0.00 \pm 0.00$ & $0.00 \pm 0.00$ & $0.90 \pm 0.40$ \\
Karyolysis & $0.00 \pm 0.00$ & $0.00 \pm 0.00$ & $0.00 \pm 0.00$ & $0.30 \pm 0.30$ & $1.20 \pm 0.49$ \\
Nephritis & $0.00 \pm 0.00$ & $0.00 \pm 0.00$ & $0.00 \pm 0.00$ & $0.90 \pm 0.24$ & $1.3 \pm 0.34^{*}$ \\
Protein Casts & $0.20 \pm 0.20$ & $0.20 \pm 0.20$ & $0.30 \pm 0.30$ & $0.20 \pm 0.20$ & $0.80 \pm 0.34$ \\
Cellular Casts & $0.00 \pm 0.00$ & $0.00 \pm 0.00$ & $0.00 \pm 0.00$ & $0.00 \pm 0.00$ & $0.00 \pm 0.00$ \\
Granular Casts & $0.40 \pm 0.24$ & $0.20 \pm 0.20$ & $0.50 \pm 0.32$ & $0.00 \pm 0.00$ & $0.30 \pm 0.30$ \\
\hline
\end{tabular}

Key: CELE = Clinacanthus nutans ethanolic leaf extract, $\mathrm{A}=$ control, $\mathrm{B}=125 \mathrm{mg} / \mathrm{kg}$ CELE, C $=250 \mathrm{mg} / \mathrm{kg}$ CELE, $\mathrm{D}=500 \mathrm{mg} / \mathrm{kg}$ CELE, $\mathrm{E}=1000 \mathrm{mg} / \mathrm{kg}$ CELE, ${ }^{*}=$ significantly different at $p<0.05$.
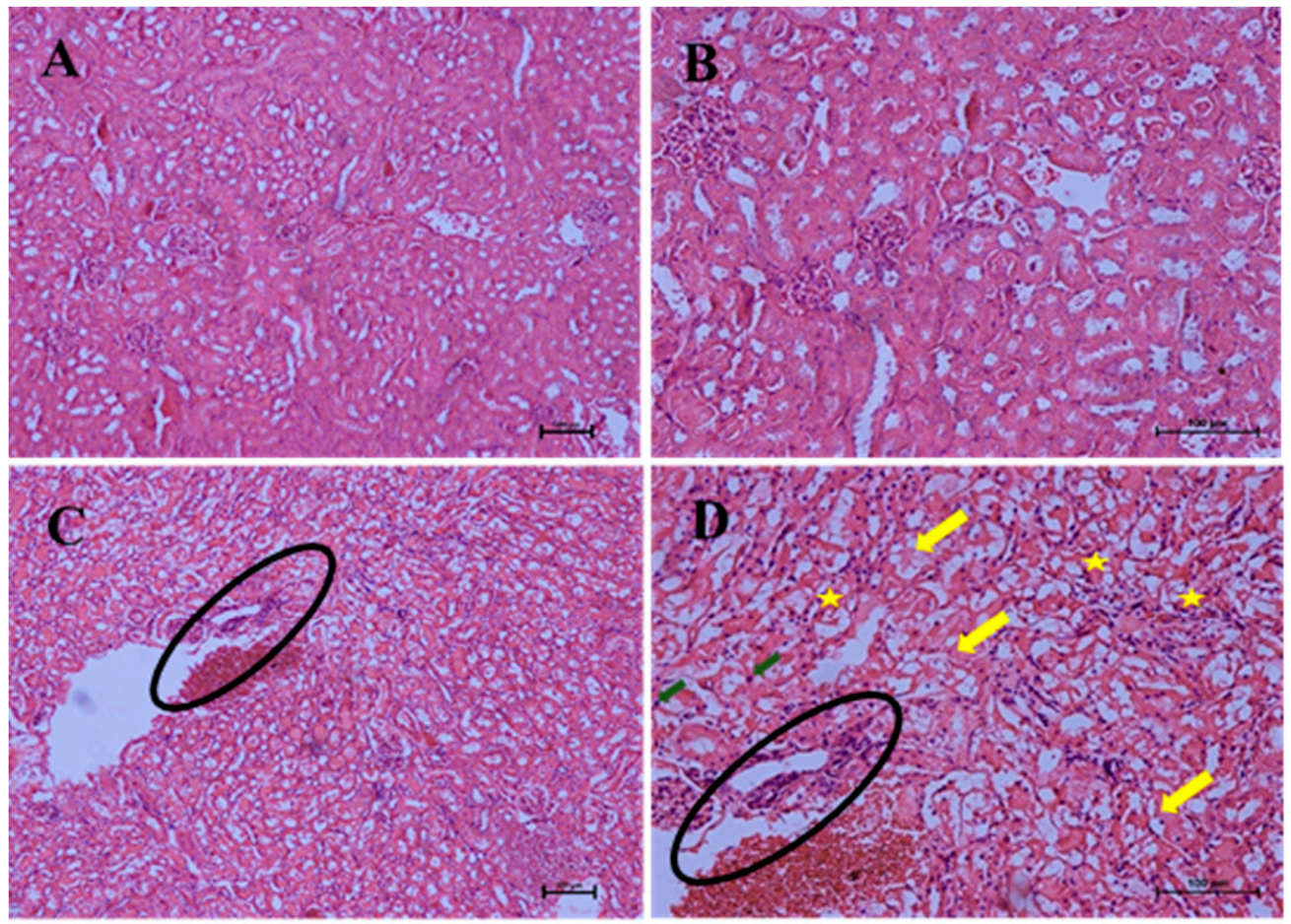

Figure 13. Effects of repeated oral administration of CELE for 28 days on the histology of kidney of female ICR mice. Key: (A) Photomicrograph of a kidney section $(\mathrm{H}$ and $\mathrm{E}$ stain $\times 100)$ from a mouse in group A showing normal architecture of kidney, (B) Higher magnification of A $(\times 200)$, (C) Photomicrograph of a kidney section $(\mathrm{H}$ and $\mathrm{E}$ stain $\times 100)$ from a mouse in group $\mathrm{E}(1000 \mathrm{mg} / \mathrm{kg}$ CELE) showing cellular infiltrations (encircled) in the kidney. (D) Photomicrograph of a kidney section $(\mathrm{H}$ and $\mathrm{E}$ stain $\times 200)$ from a mouse in group $\mathrm{E}(1000 \mathrm{mg} / \mathrm{kg}$ CELE) showing cellular infiltrations in the kidney (encircled), protein casts (yellow arrows), eosinophilic cytoplasm (star) and pyknosis of the renal tubules (green arrow), $\mathrm{CELE}=$ Clinacanthus nutans ethanolic leaf extract, $\mathrm{H}$ and $\mathrm{E}=$ haematoxylin and eosin. Scale bars represent $100 \mu \mathrm{m}$. 


\section{Discussion}

Analysis of bioactive compounds from a plant (also known as metabolomics) is considered a powerful discipline in plant sciences that is applicable in many aspects of plant biology, including aspects of growth and development, responses to external stimuli, genetics as well as nutritional requirements [22,23]. Phytochemical compounds are biologically important chemicals that occur naturally in plants. They may be responsible for colour and other organoleptic properties of plants. Phenolics, alkaloids, saponins, glycosides, terpenes, tannins, anthraquinones and steroids are some of the groups of phytochemical compounds identified in most medicinal plants $[24,25]$. These phytochemicals have been reported to be responsible for biological activities, including antioxidant, tissue protective, analgesic, antiulcer, antihypertensive, radioprotective and immunomodulatory effects, associated with most of the medicinal plants including C. nutans in both humans and animal studies [26]. Previous phytochemical investigation of $C$. nutans extracts revealed the presence of various bioactive compounds including C-glycosyl flavones [27], phytosterols, triterpenoid [28], stigmasterol, glycoglycerolipids [29], lupeol, b-sitosterol, belutin, sulphur-containing glycosides and some compounds related to chlorophyll a and chlorophyll $\mathrm{b}$. The extraction method has a significant role on the phytochemical yield of $C$. nutans extract [30]. Alam et al. [6] reported that vitexin, iso-vitexin, schaftoside, isomollupentin 7-O-bglucopyranoside, orientin and iso-orientin were isolated from the $n$-butanol and water-soluble fractions of methanolic extract of this plant in Thailand.

The results of the LC/MS/MS analyses of the C. nutans ethanolic leaf extract in this study demonstrated the presence of myricetin, orientin, iso-orientin, vitexin, iso-vitexin, isookanin, apigenin and ferulic acid as some of the important bioactive compounds of the plant. However, three of these compounds-myricetin, isookanin and ferulic acid—were additional compounds identified in the C. nutans ethanolic leaf extract cultivated in Pahang-Malaysia, which were not among the compounds identified earlier by Huang et al. [17] and Chelyn et al. [18], as well as other recent literatures as reported by Khoo et al. [31].

The identification of orientin, isoorientin, vitexin and isovitexin in this study corroborates the earlier report by Huang et al. [17] where a total of seven compounds including shaftoside (apigenin-6-C- $\beta$-D-glucopyranosyl-8-C- $\alpha$-L-arabinopyranoside), apigenin 6,8-C- $\alpha$-L-pyranarabinoside, orientin, isoorientin, isovitexin and vitexin were identified from $30 \%$ ethanol extract of C. nutans. Similarly, Chelyn et al. [18] reported that shaftoside, iso-orientin, orientin, iso-vitexin and vitexin were the major flavonoids found in the leaves of $C$. nutans cultivated in Perak, Johor, and Negri Sembilan, Malaysia [18].

Vitexin and isovitexin are bioactive compounds found in many traditional Chinese medicine and in various medicinal plants [32]. Vitexin, which is otherwise known as apigenin-8-C-glucoside, has nowadays gained increasing attention because of its diverse pharmacological activities, including antioxidant, anticancer, anti-inflammatory, neuroprotective, etc. Isovitexin, on the other hand, is an isomer of vitexin also known as apigenin-6-C-glucoside, and it is also associated with wide range of biological activities [32].

Orientin is a water-soluble flavonoid C-glycoside that is chemically known as 2-(3,4-dihydroxyphenyl)5,7-dihydrox-y-8[(2S,3R,5S,6R)-3,4,5-trihydroxy-6-(hydroxymethyl)]chromane-4-one. The compound has been isolated from different medicinal plants including Ocimum sanctum, Phyllostachys species (bamboo leaves), Passiflora species (passion flowers), Trollius species (Golden Queen) and Jatropha gossypifolia (Bellyache Bush) [33]. Orientin has been reported to be associated with various pharmacological activities including antibacterial, antiviral, anti-inflammatory, antioxidant and antiageing, among others [33]. Moreover, isoorientin is a flavone that is a 6-C-glucoside of luteolin. It has been reported to have antidiabetic, anti-inflammatory, proapoptotic and antioxidant activities.

The three additional compounds identified in this study were also reported to have various pharmacological activities. Myricetin is one of the common plant derived flavonoids that is well known for its nutraceutical activities [34]. It is one of the naturally occurring phenolic compounds in fruits, berries, vegetables, teas, medicinal plants and wines produced from various plants $[34,35]$. 
Myricetin was first isolated in India from the bark of Myrica nagi Thunb. (Myricaceae) as light yellow-coloured crystals [36]. The compound is recognised mainly for its iron-chelating, anticancer, antioxidant, anti-inflammatory and antidiabetic activities among others [34,37].

Ferulic acid belongs to the phenolic acids group that are commonly found in plant tissues [38]. It is mostly found in whole grains, grapes, parsley, spinach, oats, rhubarb and barley [39]. Similarly, ferulic acid was reported to have several physiological functions ranging from antioxidant, anti-inflammatory, antimicrobial, antidiabetic and anticancer activities [39]. It is also widely used in skin care formulations as a photoprotective agent and as an anti-skin photoageing process. However, ferulic acid is reported to have a high tendency for rapid oxidation [39-42], which could make it prone to toxicity and oxidative stress.

The presence of these compounds could be responsible for most of the pharmacological activities associated with C. nutans, including antitumor, anti-snake and insect bites, anti-VZV lesions and anti-hepatitis activities reported in the literature $[17,43,44]$. Although these compounds are reported to have potential pharmacological activities, it should be noted that the compounds could also have some adverse effects on normal cells, especially when consumed in large quantities.

The assessment of the toxic effect of plant is very necessary in evaluating its safety for both human and animal use. Evaluation of acute toxicity study of a plant or substance may perhaps provide significant information for identification of the targeted organs of the test substances following acute exposure [45]. The acute toxicity study of CELE in this study revealed that the extract at $2000 \mathrm{mg} / \mathrm{kg}$ did not cause any mortality or any signs of acute toxicity in the treated mice. The appetite and activities of the mice in both the two experimental groups were not affected by the administration of the extract throughout the period of observation. This report corroborates with the earlier reports by P'ng et al. [14], who reported that administration of C. nutans methanolic leaf extract at 900 and $1800 \mathrm{mg} / \mathrm{kg}$ is not associated with either mortality or any signs of acute toxicity in the treated mice. Similarly, Sajjaratul et al. [7] and Khoo et al. [12], respectively, reported that administration of $2000 \mathrm{mg} / \mathrm{kg}$ ethanolic extract and $5000 \mathrm{mg} / \mathrm{kg}$ aqueous extract of C. nutans did not cause any toxicity nor mortality in Sprague Dawley rats throughout the 14-day period of observation.

The significant fluctuations in the body weight gain of the mice treated with $2000 \mathrm{mg} / \mathrm{kg}$ CELE once in this study could suggests that the extract could have affected the appetite of the mice at the beginning, but shortly after, the animals have adjusted, and the extract resulted in significant weight gain at the end of the experimental period. This is in agreement with P'ng et al. [14] and Khoo et al. [12], who also recorded a significant increase in the body weight of mice and rat, respectively, administered with methanolic and aqueous C. nutans extracts. Furthermore, the changes in the body weight gain pattern were similar to that reported by Khoo et al. [12], who observed significant alteration in carbohydrate metabolism, energy metabolism and amino acid metabolism in Sprague Dawley rats treated with $5000 \mathrm{mg} / \mathrm{kg} \mathrm{C}$. nutans aqueous extract $2 \mathrm{~h}$ post administration. Nonetheless, the metabolic expression collected $24 \mathrm{~h}, 5,10$ and 15 days post-administration showed that the rats have overcome the effects of the extracts and did not show accumulation of any toxicity biomarkers [12].

The oral administration of a high dose of the extract (CELE) at $2000 \mathrm{mg} / \mathrm{kg}$ once did not affect the haematological parameters of the ICR mice significantly in this study. This may suggest further that the extract at $2000 \mathrm{mg} / \mathrm{kg}$ may not have significant effects on the metabolism $[46,47]$ of the treated mice. Correspondingly, Khoo et al. [12] reported that administration of $C$. nutans aqueous extract even at high dose of $5000 \mathrm{mg} / \mathrm{kg}$ did not affect the blood profile of Sprague Dawley rats following 14 days of observation.

Conversely, administration of the extract at $2000 \mathrm{mg} / \mathrm{kg}$ resulted in a significant increase in the levels of ALT, AST and CK, which may suggest that the extract has some adverse effects on the liver $[48,49]$ of the treated mice. Correspondingly, histopathological evaluation of liver and kidneys suggested that the extract at this high dose of $2000 \mathrm{mg} / \mathrm{kg}$ might have induced mild histopathological lesions in the liver and kidneys of the treated mice. The histopathological lesions observed in this study, including cytoplasmic vacuolation and eosinophilic cytoplasm, although not significant, may suggest 
that the plant extract at $2000 \mathrm{mg} / \mathrm{kg}$ exhibited some degree of degenerative and necrotic effects [50,51] on the liver and kidney of the treated mice. The significant differences in the liver injury markers observed in this study contradicts the earlier reports by Khoo et al. [12], where administration of $5000 \mathrm{mg} / \mathrm{kg}$ aqueous extract of C. nutans did not cause any significant changes in the levels of AST, ALT, ALP and total bilirubin between the treated and untreated groups of rats; this may perhaps be due to the differences in the extraction solvents, as water has less ability to extracts phytochemicals compared to ethanol $[30,52,53]$.

The subacute toxicity study of this research revealed significant alterations in certain parameters of the treated mice. The significant decrease in weight gain observed in the groups of mice treated with $500 \mathrm{mg} / \mathrm{kg}$ and $1000 \mathrm{mg} / \mathrm{kg}$ daily for 28 days could suggest that the extract affected the mice's feed intake [54] or has resulted in the reduction in the deposition of fats [46,55]. Reduction in the body weight gain has been reported to be associated with toxicity following exposure to potential toxic chemical or substances in animals [56,57]. These findings are in agreement with the report of Chavalittumrong et al. [58], where a significant decrease body weight of male rats treated with $1.0 \mathrm{~g} / \mathrm{kg}$ of $C$. nutans ethanolic extract daily for 90 days compared to the control group was reported. However, it is contrary to the report of Zakaria et al. [9], who reported that repeated oral administration of methanolic extract of $C$. nutans daily for 28 days did not affect the body weight of the mice even at the highest dose of $2500 \mathrm{mg} / \mathrm{kg}$. This perhaps may be due to shorter duration of exposure [56,57] compared to the present study.

The repeated oral administration of the extract at $125 \mathrm{mg} / \mathrm{kg}, 250 \mathrm{mg} / \mathrm{kg}, 500 \mathrm{mg} / \mathrm{kg}$ and $1000 \mathrm{mg} / \mathrm{kg}$ daily for 28 days in this study did not affect the haematological parameters of the ICR mice significantly, suggesting that the metabolic processes of the mice were not significantly affected $[59,60]$ by the administration of the extract.

The mean corpuscular volume (MCV) is used to classify anaemia as microcytic (below the normal range), normocytic (within the normal range) or macrocytic (above the normal range) [61,62]. Therefore, the significant alterations in the values of MCV observed in this study could suggest that the extract has macrocytic effect on the RBC of the treated mice. Similarly, the mean corpuscular haemoglobin $(\mathrm{MCH})$ and the mean corpuscular haemoglobin concentration $(\mathrm{MCHC})$ are also used as indices for diagnosis of anaemia. Decreased level of MCHC may indicate hypochromasia in early iron deficiency anaemia [63]. Therefore, the significant increase in the level of MCH observed in this study could suggests that the extract might have certain compounds capable of promoting haemoglobin production and this is in agreement with the report of Archibong et al. [61].

The results of plasma biochemical parameters showed that daily oral administration of CELE for 28 days at 500 and $1000 \mathrm{mg} / \mathrm{kg}$ doses has effect on some plasma biochemical parameters. The significant increase in creatinine level detected in the group of mice treated with $1000 \mathrm{mg} / \mathrm{kg}$ daily for 28 days could suggest that the extract especially at higher doses of 500 and $1000 \mathrm{mg} / \mathrm{kg}$ may possess some adverse effects on the kidneys of the ICR mice $[48,64,65]$. This is because creatinine, which is the product of creatine metabolism, is solely excreted by the kidneys; therefore, any injury to the kidneys may result in hypercreatinaemia [66]. These findings were similar to the report of Zakaria et al. [9], where there was significant increase in the level of creatinine in both male and female mice treated with both 500 and $1000 \mathrm{mg} / \mathrm{kg}$ C. nutans repeatedly for 28 days. However, Chavalittumrong et al. [58] reported a significant decrease in creatinine levels in the male rats treated with $1000 \mathrm{mg} / \mathrm{kg} \mathrm{C.} \mathrm{nutans}$ ethanolic extract daily for 90 days compared to the control. The significant increase in the levels of ALT observed in this study at 500 and $1000 \mathrm{mg} / \mathrm{kg}$, could suggest that the extract at this high doses might have affected the normal function of liver in the treated mice $[48,49,67]$. This was further supported by the results of the histopathological evaluation of liver and kidney in this study.

The histopathological evaluation of liver and kidney of the experimental mice in this study revealed that daily oral administration of CELE for 28 days at $1000 \mathrm{mg} / \mathrm{kg}$ dose resulted in various hepatic and renal lesions. The significant hepatic degeneration and necrosis observed histopathologically in the group of mice administered with daily oral doses of CELE at $1000 \mathrm{mg} / \mathrm{kg}$ for 28 days were suggestive 
of toxic or adverse effects $[7,50,51,68-70]$ of the extract on the animals, as earlier observed in the results of plasma biochemical parameters for hepatic injury markers (ALT and AST). Similarly, the renal tubular degeneration and necrosis observed in this research further supported the results of plasma biochemical parameters, providing further indication that administration of the extract at $1000 \mathrm{mg} / \mathrm{kg}$ is not safe [50,51] for the female ICR mice. Severe hepatic damage has been reported to be associated with oxidative stress and depletion of ATP leading to necrosis of the hepatocytes [71,72].

P'ng et al. [13] reported that Food and Agricultural Materials Inspection Centre (FAMIC) uses the acceptable daily intake (ADI) to determine the non-toxic level of a test substance to humans based on the non-observable adverse effect level (NOAEL) value obtained from animal trials [13]. Based on the results of this study, the NOAEL of ethanolic leaf extract of C. nutans was $250 \mathrm{mg} / \mathrm{kg}$ in mice, whereas the low observable adverse effect level was $500 \mathrm{mg} / \mathrm{kg}$ in mice. Therefore, the ADI of C. nutans ethanolic leaf extract was determined to be $2.5 \mathrm{mg} / \mathrm{kg}$, according to the method described by P'ng et al. [13]

\section{Materials and Methods}

\subsection{Plant Materials}

Fresh leaves of the plant C. nutans were obtained from Malaysian Agriculture Research and Development Institute (MARDI) research station, Muadzam Shah, Pahang-Malaysia, from July to October 2017. The leaves were washed to remove dirt and soil deposits, dried under the sun for $48 \mathrm{~h}$ to remove moisture content. Subsequently, the leaves were ground into powder form and stored at $4{ }^{\circ} \mathrm{C}$ for further analyses [73].

\subsubsection{Botanical Identification}

The plant C. nutans was identified botanically at the Faculty of Science and Technology (FST), University Kebangsaan Malaysia (UKM). Its kingdom, family and species were confirmed. The voucher specimen for the plant was deposited in the herbarium of FST, UKM (UKMB40367).

\subsubsection{Extraction Procedure}

The dried powdered leaves of $C$. nutans were extracted using absolute ethanol at the ration of 1:40. One hundred grams (100 g) of C. nutans powdered leaves was dissolved in $4000 \mathrm{~mL}$ of absolute ethanol in a clean glass flask [74]. The flasks was covered with aluminium foil and placed in an orbital shaker (Heidolph Unimax 1010, Schwabach, Germany) at $200 \mathrm{rpm}$ for about $2 \mathrm{~h}$ at room temperature [7,75,76]. The extract was filtered twice using Whatman No. 1 filter paper and concentrated using rotary evaporator (BUCHI Rotavapor R-200, Flawil, Switzerland). The concentrated extracts were combined together [77]. The concentrated extracts were then freeze-dried in a freeze-dryer (The Virtis Company, Gardiner, NY, USA) and obtained in both freeze-dried (for LC-MS) and semisolid (for toxicity studies) forms and were stored at $-20^{\circ} \mathrm{C}$ and $4{ }^{\circ} \mathrm{C}$ respectively until needed for the experiments [78].

\subsubsection{Preparation of Extracts}

Dry extract of the plant leaf was weighed and dissolved in the solvents ( $5 \%$ DMSO) to prepare the desired stock solution of the extracts from which the dose was calculated according to the mice's body weight [79].

\subsection{Liquid Chromatography Mass Spectrometry (LC-MS)}

\subsubsection{Sample Preparation}

One gram (1 g) of CELE was weighed into $1 \mathrm{~mL}$ of LC-MS-grade methanol (as solvent), the mixture was sonicated using Bransonic Ultra sonic cleaner (2510E-DTH, Branson Ultrasonics Corporation, Danbury, CT, USA) at $25^{\circ} \mathrm{C}$ for $5 \mathrm{~min}$ to dissolve the solute appropriately. The samples were then 
filtered using satorius NY $0.45 \mu \mathrm{m}$ filter paper into LC-MS (HPLC) vials. The vials were then taken into the LC-MS machine for analyses.

\subsubsection{Chemicals and Equipment}

Standard compounds: LC-MS-grade acetonitrile (ACN), formic acid and methanol (MeOH) were obtained from Fisher Scientific (Fair Lawn, NJ, USA). LC-MS-grade water (18 MX) was prepared using a Millipore Milli-Q purification system (Millipore Corporation, Bedford, MA, USA).

High-performance liquid chromatography (HPLC) separation was performed using a Thermo Scientific $^{\text {TM }}$ Dionex Ultimate 3000 LC system (Thermo Fisher Scientific, Waltham, MA, USA) with a Thermo Hypersil Gold aQ $(1.9 \mu \mathrm{m}, 100 \mathrm{~mm} \times 2.1$ diameter $)$. A Thermo Scientific Q Exactive Focus (Thermo Fisher Scientific, USA) equipped with a pump: HGP-3200RS, Autosampler: WPS3000TRS, column compartment: TCC3000RS, a degasser: SRD3400, Diode Array Detector (DAD), Orbitrap mass analyser with a heated-electrospray ionization (H-ESI II), and software of Xcalibur and Chromaleon was used for LC-MS and LC-MS/MS detection.

\subsubsection{Compound Identification}

The method of Huang et al. [17] was employed with modifications for the qualitative identification of compounds in the crude extract of CELE. The high-performance liquid chromatography (HPLC) separation was performed with mobile phase consisting of two different solvents: $C$ and $D$ in linear gradient. Solvent $C$ was $0.1 \%$ formic acid $(v / v)$ in water whereas solvent $\mathrm{D}$ was methanol. The gradient was set at $1-90 \% \mathrm{D}$ in C over a period of $45 \mathrm{~min}$ at a flow rate of $0.2 \mathrm{~mL} / \mathrm{min}$. The injection volume was $10 \mu \mathrm{L}$ and the UV detector was set at $280 \mathrm{~nm}$ [17]. The eluent was monitored by a Thermo Scientific ion max API source (H-ESI II), under both positive and negative ion modes and scanned from $\mathrm{m} / \mathrm{z} 190$ to 800 . ESI was conducted by using a needle voltage of $4.2 \mathrm{kV}$ and $3.5 \mathrm{kV}$ for positive and negative modes respectively under optimum collision energy level of 30. High-purity nitrogen $(99.999 \%)$ was used as dry gas and at a flow rate of $12 \mathrm{~L} / \mathrm{min}$ and capillary temperature at $320^{\circ} \mathrm{C}$. Nitrogen was used as nebulizer at $40 \mathrm{psi}[80]$.

\subsection{Acute and Subacute Toxicity Studies of C. nutans Ethanolic Leaf Extract}

The acute and subacute toxicity effects of the plant were studied according to OECD guidelines 425 and 407, respectively; with slight modification on the selection of gender of the experimental animals for the subacute toxicity testing. We chose to test the toxic effects of $C$. nutans on female ICR mice only (but not on the male). This is because female animals were reported to be more susceptible to toxic substances than their male counterparts [81]. Moreover, OECD guideline 425 reported that "testing in one sex (usually females) is generally considered sufficient". This would minimize the number of animals required to estimate the possible toxicity of the plant extract (C. nutans).

The experiment was conducted at the Animal Metabolism, Toxicology and Reproductive Centre (AMTREC), Malaysian Agricultural Research and Development Institute (MARDI), Serdang. This research adhered to the guide for the care and use of laboratory animals and was approved by the Animal Ethics Committee (AEC) of MARDI with the approval reference number: 20170717/R/MAEC00023. The mice were acclimatized for 1 week to the housing conditions, with temperature within the range of 22 to $25^{\circ} \mathrm{C}$, humidity at the range of $40 \%$ to $70 \%$ and balance of $12 \mathrm{~h}$ light $/ 12 \mathrm{~h}$ dark cycle. The bedding and water were replaced regularly, and the cages were cleaned accordingly. Each mouse was placed in a polycarbonate plastic cage. The animal used in this study were purchased from a commercial vendor at Selangor, Malaysia.

A total of 10 8-week-old female mice were used for the acute toxicity study. The mice were divided into two groups of five mice each: groups A and B. Group A received distilled water and served as control group, while group B received a single dose of $2000 \mathrm{mg} / \mathrm{kg}$ CELE by oral gavage [82] using stainless steel needle. The extract and distilled water were administered at the volume of $1 \mathrm{~mL}$ per $100 \mathrm{~g}$ body weight of the average body weight of each group of mice. The mice were fasted for 
2-3 $\mathrm{h}$ prior to the administration of the extracts. Thereafter, all mice had free access to water and commercial chow ad libitum throughout the period of observation. The mice were monitored for mortality, behavioural signs (restlessness, dullness, agitation) and sign of toxicity, daily for 14 days [7].

For the subacute toxicity study, a total of 25 8-week-old female mice were divided into 5 groups of 5 mice each: groups A (control), B (125 mg/kg), C (250 mg/kg), D (500 mg/kg) and E (1000 mg/kg). The extract (CELE) was dissolved in 5\% dimethyl sulfoxide (DMSO) and administered to groups B, C, $\mathrm{D}$ and $\mathrm{E}$ accordingly. The extract was administered once daily for 28 days at a volume of $1 \mathrm{~mL} / 100 \mathrm{~g}$ body weight, via oral gavage using stainless steel needle. Group A received distilled water (vehicle) only at the same $1 \mathrm{~mL} / 100 \mathrm{~g}$ body weight. The mice were monitored daily for any signs of toxicity and sacrificed on day 29 of the experiment using $\mathrm{CO}_{2}$ chamber.

\subsubsection{Determination of Weekly Body Weight and Body Weight Gain}

The body weight of each mouse in each of the experimental groups was measured weekly using electric weighing scale and recorded according to the method of Sajjaratul et al. [7]. The weekly body weight gain was calculated by subtracting the previous weekly body weight of each mouse from that the current week.

\subsubsection{Collection of Blood and Organ Samples}

The mice were sacrificed humanely on days 15 and 29 of the experiments for the acute and subacute toxicity studies respectively, using $\mathrm{CO}_{2}$ chamber $[83,84]$. Blood samples were collected from the heart [83] into clean bottles containing EDTA as an anticoagulant for haematological and blood chemistry analysis $[82,84,85]$. All mice were subjected to gross necropsy and tissues were collected from liver, kidney, heart, brain, spleen, lungs and uterus. The weight of each organ was measured and recorded. The relative organs weight was calculated by dividing the weight of each organ with the body weight of the corresponding mouse in each group [79].

$$
\text { Relative organ weight }=\frac{\text { organ weight }}{\text { body weight }} \times 100
$$

\subsubsection{Haematological Analyses}

The blood samples collected were analysed for complete blood count using an automated haematology analyser (ABC Vet ${ }^{\circledR}$, ABX Diagnostics, Montpellier, France) for the total RBC, WBC, platelet count, haemoglobin $(\mathrm{Hb})$ concentration, mean corpuscular volume $(\mathrm{MCV})$ and mean corpuscular haemoglobin concentration (MCHC). Blood smears were prepared and stained with Wright stain and examined under a light microscope. Differential WBC count was determined manually by counting 100 WBC on the blood smears. The absolute values of each type of WBC (neutrophils, eosinophils, basophils, lymphocytes and monocytes) was calculated by multiplying the percentage of each WBC type to the total WBC count from the automated analyser $[7,86]$.

\subsubsection{Clinical Biochemistry Analysis}

The blood samples collected in EDTA bottles were centrifuged for $15 \mathrm{~min}$ at $3000 \mathrm{rpm}$ to obtain plasma for biochemical analyses $[82,84,85,87-90]$. The plasma was further analysed for urea, creatinine, creatinine kinase (CK), total protein (TP), albumin (ALB), aspartate aminotransferase (AST) and alanine aminotransferase (ALT) using a fully automated clinical chemistry analyser (BioLis 24i Chemistry Analyzer, Tokyo, Japan) $[7,84,86]$. The values for globulins were calculated manually by subtracting the values of albumin from that of total protein [84].

\subsubsection{Histopathological Evaluation}

Post-mortem was conducted on each of the mouse, liver and kidneys were collected for histopathological evaluation at the histopathology laboratory, Faculty of Veterinary Medicine, 
Universiti Putra Malaysia. Collected organs were fixed in 10\% neutral buffered formalin and processed further for haematoxylin and eosin stain as described by Nurul et al. [91] and Aliyu et al. [84]. The severity of each of the lesions was also scored according to the method of Nurul et al. [91] with modifications. The scores of each lesion and its interpretation is presented on Table 12.

Table 12. Interpretation of scores in liver and kidney lesion scoring for the toxicity studies of CELE in ICR mice.

\begin{tabular}{ccc}
\hline$*$ Score & Percentage & Severity \\
\hline 0 & NONE & NONE \\
1 & Less than $10 \%$ & Mild \\
1.5 & $10-30 \%$ & Mild-moderate \\
2 & $30-50 \%$ & Moderate \\
2.5 & $50-70 \%$ & Moderate-severe \\
3 & More than $70 \%$ & Severe \\
\hline
\end{tabular}

Key: CELE $=$ Clinacanthus nutans ethanolic leaf extract, ${ }^{*}=$ Modified from Sajjaratul et al. [7] and Nurul et al. [91].

\subsection{Statistical Analysis}

Statistical analyses were performed using *IBM *SPSS statistics version 23 [84]. Data was presented as mean \pm standard error of the mean (SEM). Results from the body weight, relative organ weights, haematological and plasma biochemical analyses were accordingly subjected to Student's $t$ test statistical tool (between two treatment groups) as well as one-way analysis of variance (ANOVA) statistical tool with Tukey post hoc test (between three or more treatment groups). However, the results from the histopathological lesion scoring were analysed using nonparametric Mann-Whitney $U$ test tool (between two treatment groups) and nonparametric Kruskal-Wallis $\mathrm{H}$ statistical tool (between three or more treatment groups). $p$-values $<0.05$ were considered statistically significant.

\section{Conclusions}

In conclusion, C. nutans ethanolic leaf extract cultivated in Pahang-Malaysia contained additional bioactive compounds compared to those cultivated in Perak, Johor and Negri Sembilan as reported earlier in the literature. Moreover, the lethal dose $50\left(\mathrm{LD}_{50}\right)$ of CELE in mice is greater than $2000 \mathrm{mg} / \mathrm{kg}$, as there was no mortality observed. Moreover, single oral administration of the extracts at $2000 \mathrm{mg} / \mathrm{kg}$ has no toxic effects on the haematological parameters of ICR mice; however, administration of the extracts once at $2000 \mathrm{mg} / \mathrm{kg}$ induced mild hepatic and renal histological alterations in the mice. Similarly, repeated daily oral administration of CELE for 28 days induced mild to moderate hepatic degeneration at $500 \mathrm{mg} / \mathrm{kg}$ and hepatic and renal necrosis at $1000 \mathrm{mg} / \mathrm{kg}$ in female ICR mice. Therefore, the plant extract should be taken with caution as food supplement and/or alternative medicine. It is recommended that the subchronic and even chronic toxicity effects of the extract be evaluated.

Author Contributions: Conceptualisation, A.A., M.R.S., K.S. and H.H.; Data curation, A.A.; Formal analysis, A.A.; Funding acquisition, H.H.; Investigation, A.A., M.R.S. and H.H.; Methodology, A.A., M.R.S., N.S.A.S., M.F.H.R., K.S. and H.H.; Project administration, H.H.; Resources, M.R.S., S.S. and H.H.; Supervision, S.S., M.M.N., K.S. and H.H.; Validation, M.M.N., K.S. and H.H.; Writing-original draft, A.A.; Writing-review and editing, A.A. and H.H. All authors have read and agreed to the published version of the manuscript.

Funding: This research work was supported by IPS Research Grant (IPS/2018/9594600) Universiti Putra Malaysia, and PhD scholarship was provided by Tertiary education trust fund (TETFUND) Nigeria (Ref: TETFUND/ES/AST\&D/UDU/SOKOTO/VOL.1/05/25/2016). 
Acknowledgments: The authors appreciate the contributions of the Malaysian Agricultural Research Development Institute (MARDI), the staff of Laboratory of Natural Products, Institute of Bioscience (En Azizul Isa, Pn Zurina Zainal and En Ahmad Fauzi Mokhtar) and the staff of the Haematology and Clinical Biochemistry and Histopathology Laboratories, Faculty of Veterinary Medicine (Pn Darulmuqaamah Masud, Pn Noorain Azman, En Abdullah Misron, En Arman Addelan, Pn Jamila Jahari, Pn Latifah Mohd Hanan Cik Zainatuaishah Abdul Manap), Universiti Putra Malaysia (UPM) for providing technical support in carrying out this research. The contributions of Muhammad Afiq Bin Ngadni of Laboratory of Natural Product, IBS and Yahaya Yakubu of the Faculty of Sciences, UPM are highly acknowledged.

Conflicts of Interest: The authors declare no conflicts of interest.

\section{References}

1. Ismail, M.; Bagalkotkar, G.; Iqbal, S.; Adamu, H.A. Anticancer properties and phenolic contents of sequentially prepared extracts from different parts of selected medicinal plants indigenous to malaysia. Molecules 2012, 17, 5745-5756. [CrossRef] [PubMed]

2. Yahya, R.; Dash, G.K.; Abdullah, M.S.; Mathews, A. Clinacanthus nutans (burm. F.) Lindau: An Useful Medicinal Plant of South-East Asia. Int. J. Pharmacogn. Phytochem. Res. 2015, 7, 1244-1250.

3. Isitua, C.C.; Lozano, M.J.S.; Jaramillo, C.; Farmacia, P.P.; De Ciencias, F.; Salud, D.; Tecnica, U.; Machala, D.; Panamericana, A.; Machala, P.; et al. Phytochemical and nutritional properties of dried leaf powder of Moringa oleifera Lam. from machala el oro province of ecuador. Asian J. Plant Sci. Res. 2015, 5, 8-16.

4. Kunsorn, P.; Ruangrungsi, N.; Lipipun, V.; Khanboon, A.; Rungsihirunrat, K. The identities and anti-herpes simplex virus activity of Clinacanthus nutans and Clinacanthus siamensis. Asian Pac. J. Trop. Biomed. 2013, 3, 284-290. [CrossRef]

5. Yusmazuru, Z.; Lin, W.Y.; Fakhuruddin, N.H. Anti-Cancer Effects of Clinacanthus nutans Extract towards Human Cervical Cancer Cell. J. Biomed. Clin. Sci. 2017, 2, 11-19.

6. Alam, A.; Ferdosh, S.; Ghafoor, K.; Hakim, A.; Juraimi, A.S.; Khatib, A.; Sarker, Z.I. Clinacanthus nutans: A review of the medicinal uses, pharmacology and phytochemistry. Asian Pac. J. Trop. Med. 2016, 9, 402-409. [CrossRef]

7. Sajjarattul, N.N.A.; Hazilawati, H.; Rosly, S.M.; Shanmugavelu, S.; Noordin, M.M. Blood Profiles and Histopathological Changes of Liver and Kidney Tissues from Male Sprague Dawley Rats Treated with Ethanol Extracts of Clinacanthus nutans Leaf. J. Clin. Toxicol. 2016, 6. [CrossRef]

8. Alam, A.; Ghafoor, K. Clinacanthus nutans: A review of the medicinal uses, pharmacology and phytochemistry Asian Paci fi c Journal of Tropical Medicine. Asian Pac. J. Trop. Med. 2016, 9, 1-8. [CrossRef]

9. Zakaria, Z.A.; Hafiz, M.; Rahim, A.; Mohtarrudin, N.; Kadir, A.; Cheema, M.S.; Ahmad, Z.; Mooi, C.S.; Tohid, S.F.; Building, F.F.; et al. Acute and sub-chronic oral toxicity studies of methanolic extract of Clinacanthus nutans in mice. African J. Tradit. Complement. Altern. Med. 2016, 13, 210-222. [CrossRef]

10. Hao, D.; Xu, Y.; Zhao, M.; Ma, J.; Wei, Y.; Wang, X. Biosynthesis of Clinacanthus nutans Lindau leaf extract mediated ag NPs, au NPs and their comparative strong muscle relaxant, analgesic activities for pain management in nursing care for using in intensive nursing care unit. J. Photochem. Photobiol. B Biol. 2020, 202, 111674. [CrossRef]

11. Farsi, E.; Esmailli, K.; Shafaei, A.; Moradi Khaniabadi, P.; Al Hindi, B.; Khadeer Ahamed, M.B.; Sandai, D.; Abdul Sattar, M.; Ismail, Z.; Abdul Majid, A.M.S.; et al. Mutagenicity and preclinical safety assessment of the aqueous extract of Clinacanthus nutans leaves. Drug Chem. Toxicol. 2016, 39, 461-473. [CrossRef] [PubMed]

12. Khoo, L.; Foong Kow, A.; Maulidiani, M.; Lee, M.; Tan, C.; Shaari, K.; Tham, C.; Abas, F. Hematological, Biochemical, Histopathological and 1H-NMR Metabolomics Application in Acute Toxicity Evaluation of Clinacanthus nutans Water Leaf Extract. Molecules 2018, 23, 2172. [CrossRef] [PubMed]

13. P'ng, X.W.; Akowuah, G.A.; Chin, J.H. Evaluation of the sub-acute oral toxic effect of methanol extract of Clinacanthus nutans leaves in rats. J. Acute Dis. 2013, 2, 29-32. [CrossRef]

14. P'ng, X.W.; Akowuah, G.A.; Chin, J.H. Acute Oral Toxicity Study of Clinacanthus nutans in Mice. Int. J. Pharm. Sci. Res. 2012, 3, 4202-4204.

15. Murugesu, S.; Khatib, A.; Ahmed, Q.U.; Ibrahim, Z.; Uzir, B.F.; Benchoula, K.; Yusoff, N.I.N.; Perumal, V.; Alajmi, M.F.; Salamah, S.; et al. Toxicity study on Clinacanthus nutans leaf hexane fraction using Danio rerio embryos. Toxicol. Reports 2019, 6, 1148-1154. [CrossRef] 
16. Tu, S.F.; Liu, R.H.; Cheng, Y.B.; Hsu, Y.M.; Du, Y.C.; El-Shazly, M.; Wu, Y.C.; Chang, F.R. Chemical constituents and bioactivities of Clinacanthus nutans aerial parts. Molecules 2014, 19, 20382-20390. [CrossRef]

17. Huang, D.; Guo, W.; Gao, J.; Chen, J.; Olatunji, J.O. Clinacanthus nutans (Burm. f.) lindau ethanol extract inhibits hepatoma in mice through upregulation of the immune response. Molecules 2015, 20, 17405-17428. [CrossRef]

18. Chelyn, J.L.; Omar, M.H.; Mohd Yousof, N.S.A.; Ranggasamy, R.; Wasiman, M.I.; Ismail, Z. Analysis of Flavone C. Glycosides in the Leaves of Clinacanthus nutans (Burm. f.) Lindau by HPTLC and HPLC-UV/DAD. Sci. World J. 2014, 2014, 1-6. [CrossRef]

19. Iqbal, S.; Bhanger, M.I. Effect of season and production location on antioxidant activity of Moringa oleifera leaves grown in Pakistan. J. Food Compos. Anal. 2006, 19, 544-551. [CrossRef]

20. Mendieta-Araica, B.; Spörndly, E.; Reyes-Sánchez, N.; Salmerón-Miranda, F.; Halling, M. Biomass production and chemical composition of Moringa oleifera under different planting densities and levels of nitrogen fertilization. Agrofor. Syst. 2013, 87, 81-92. [CrossRef]

21. Förster, N.; Ulrichs, C.; Schreiner, M.; Arndt, N.; Schmidt, R.; Mewis, I. Ecotype Variability in Growth and Secondary Metabolite Profile in Moringa oleifera: Impact of Sulfur and Water Availability. J. Agric. Food Chem. 2015, 63, 2852-2861. [CrossRef] [PubMed]

22. Schauer, N.; Fernie, A. Plant metabolomics: Towards biological function and mechanism. Trends Plant Sci. 2006, 11, 508-516. [CrossRef]

23. Tan, C.X.; Chong, G.H.; Hamzah, H.; Ghazali, H.M. Effect of virgin avocado oil on diet-induced hypercholesterolemia in rats via $1 \mathrm{H}$ NMR-based metabolomics approach. Phyther. Res. 2018, 32, 2264-2274. [CrossRef]

24. Varma, N. Phytoconstituents and Their Mode of Extractions: An Overview. Res. J. Chem. Environ. Sci. 2016, 4, 8-15.

25. Bakar Sajak, A.A.; Azlan, A.; Hamzah, H.; Abas, F. Phenolic Content and $\alpha$-glucosidase Inhibitory Activity of Herbal Mixture: Effect of processing technique and honey ratio. Malaysian J. Med. Heal. Sci. 2019, 15, 58-63.

26. Farsi, E.; Abdul Majid, A.S.; Abdul Majid, A.M. Clinacanthus nutans, Yesterday's Practice and Future's Drug: A Comprehensive Review. Am. J. Phytomedicine Clin. Ther. 2016, 4, 113-126.

27. Zhang, Y.; Jiao, J.; Liu, C.; Wu, X.; Zhang, Y. Isolation and purification of four flavone C-glycosides from antioxidant of bamboo leaves by macroporous resin column chromatography and preparative high-performance liquid chromatography. Food Chem. 2007, 107, 1326-1336. [CrossRef]

28. Dampawan, P.; Huntrakul, C.; Reutrakul, V. Constituents of Clinacanthus nutans and the crystal structure of LUP-20 (29)-ene-3-one. J. Sci. Soc. Thailand 1977, 1, 53-62.

29. Sakdarat, S.; Shuyprom, A.; Pientong, C.; Ekalaksananan, T.; Thongchai, S. Bioactive constituents from the leaves of Clinacanthus nutans Lindau. Bioorg. Med. Chem. 2009, 17, 1857-1860. [CrossRef]

30. Mustapa, A.N.; Martin, Á.; Mato, R.B.; Cocero, M.J. Extraction of phytocompounds from the medicinal plant Clinacanthus nutans Lindau by microwave-assisted extraction and supercritical carbon dioxide extraction. Ind. Crops Prod. 2015, 74, 83-94. [CrossRef]

31. Khoo, L.W.; Audrey Kow, S.; Lee, M.T.; Tan, C.P.; Shaari, K.; Tham, C.L.; Abas, F. A Comprehensive Review on Phytochemistry and Pharmacological Activities of Clinacanthus nutans (Burm.f.) Lindau. Evid.-Based Complement. Altern. Med. 2018, 2018, 1-39. [CrossRef] [PubMed]

32. He, M.; Min, J.-W.; Kong, W.-L.; He, X.-H.; Li, J.-X.; Peng, B.-W. A review on the pharmacological effects of vitexin and isovitexin. Fitoterapia 2016, 115, 74-85. [CrossRef] [PubMed]

33. Lam, K.Y.; Ling, A.P.K.; Koh, R.Y.; Wong, Y.P.; Say, Y.H. A Review on Medicinal Properties of Orientin. Adv. Pharmacol. Sci. 2016, 2016, 1-9. [CrossRef] [PubMed]

34. Semwal, D.K.; Semwal, R.B.; Combrinck, S.; Viljoen, A. Myricetin: A dietary molecule with diverse biological activities. Nutrients 2016, 8, 90. [CrossRef] [PubMed]

35. Park, K.-S.; Chong, Y.; Kim, M.K. Myricetin: Biological activity related to human health. Appl. Biol. Chem. 2016, 59, 259-269. [CrossRef]

36. Perkin, A.G.; Hummel, J.J. LXXVI.-The colouring principle contained in the bark of Myrica nagi. Part I. J. Chem. Soc., Trans. 1896, 69, 1287-1294. [CrossRef]

37. Ong, K.C.; Khoo, H.-E. Biological effects of myricetin. Gen. Pharmacol. Vasc. Syst. 1997, 29, 121-126. [CrossRef]

38. Mattila, P.; Kumpulainen, J. Determination of free and total phenolic acids in plant-derived foods by HPLC with diode-array detection. J. Agric. Food Chem. 2002, 50, 3660-3667. [CrossRef] 
39. Zduńska, K.; Dana, A.; Kolodziejczak, A.; Rotsztejn, H. Antioxidant Properties of Ferulic Acid and Its Possible Application. Skin Pharmacol. Physiol. 2018, 31, 332-336. [CrossRef]

40. Bezerra, G.S.N.; Pereira, M.A.V.; Ostrosky, E.A.; Barbosa, E.G.; de Moura, M.F.V.; Ferrari, M.; Aragão, C.F.S.; Gomes, A.P.B. Compatibility study between ferulic acid and excipients used in cosmetic formulations by TG/DTG, DSC and FTIR. J. Therm. Anal. Calorim. 2017, 127, 1683-1691. [CrossRef]

41. Tee-ngam, P.; Nunant, N.; Rattanarat, P.; Siangproh, W.; Chailapakul, O. Simple and Rapid Determination of Ferulic Acid Levels in Food and Cosmetic Samples Using Paper-Based Platforms. Sensors 2013, 13, 13039-13053. [CrossRef] [PubMed]

42. Moldovan, M.; Lahmar, A.; Bogdan, C.; Parauan, S.; Tomuţă, I.; Crişan, M. Formulation and evaluation of a water-in-oil cream containing herbal active ingredients and ferulic acid. Clujul Med. 2017, 90, 212-219. [CrossRef] [PubMed]

43. Fattovich, G.; Stroffolini, T.; Zagni, I.; Donato, F. Hepatocellular carcinoma in cirrhosis: Incidence and risk factors. Gastroenterology 2004, 127, S35-S50. [CrossRef]

44. Sakdarat, S.; Shuyprom, A.; Dechatiwongse, T.; Ayudhya, N.; Waterman, P.G.; Karagianis, G. Chemical composition investigation of the Clinacanthus nutans Lindau leaves. Thai J. Phytopharm. 2008, 15, $13-24$.

45. Timbrell, J.A. Principles of Biochemical Toxicology, 4th ed.; CRC Press: New York, NY, USA, 2008; ISBN 9780429124938.

46. Priestman, D.A.; Van Der Spoel, A.C.; Butters, T.D.; Dwek, R.A.; Platt, F.M. N-butyldeoxynojirimycin causes weight loss as a result of appetite suppression in lean and obese mice. Diabetes Obes. Metab. 2008, 10, 159-166. [CrossRef] [PubMed]

47. Tamsir, N.M.; Esa, N.M.; Shafie, N.H.; Hussein, M.Z.; Hamzah, H.; Abdullah, M.A. The Acute Effects of Oral Administration of Phytic Acid-Chitosan-Magnetic Iron Oxide Nanoparticles in Mice. Int. J. Mol. Sci. 2019, 20, 4114. [CrossRef] [PubMed]

48. Brush, B.M. Interpretation of Laboratory Results for Small Animal Clinicians. J. Small Anim. Pract. 1991, 33, 25-34.

49. Tennant, B.C.; Center, S.A. Hepatic Function. In Clinical Biochemistry of Domestic Animals; Elsevier: Amsterdam, The Netherlands, 2008; pp. 379-412. ISBN 9780123704917.

50. Itagaki, S.; Nishida, E.; Lee, M.-J.; Doi, K. Histopathology of subacute renal lesions in mice induced by streptozotocin. Exp. Toxicol. Pathol. 1995, 47, 485-491. [CrossRef]

51. Kiss, N.; Hamar, P. Histopathological Evaluation of Contrast-Induced Acute Kidney Injury Rodent Models. Biomed Res. Int. 2016, 2016, 1-15. [CrossRef]

52. Tan, M.C.; Tan, C.P.; Ho, C. Effects of extraction solvent system, time and temperature on total phenolic content of henna (Lawsonia inermis) stems. Int. Food Res. J. 2013, 20, 3117-3123.

53. Tan, C.X.; Chong, G.H.; Hamzah, H.; Ghazali, H.M. Characterization of Virgin Avocado Oil Obtained via Advanced Green Techniques. Eur. J. Lipid Sci. Technol. 2018, 120, 1800170. [CrossRef]

54. Ogbonnia, S.; Mbaka, G.; Anyika, E.; Osegbo, O.; Igbokwe, N. Evaluation of acute toxicity in mice and subchronic toxicity of hydro-ethanolic extract of Chromolaena odorata (L.) King and Robinson (Fam. Asteraceae) in rats. Agric. Biol. J. North Am. 2010, 1, 859-865. [CrossRef]

55. Harizal, S.N.; Mansor, S.M.; Hasnan, J.; Tharakan, J.K.J.; Abdullah, J. Acute toxicity study of the standardized methanolic extract of Mitragyna speciosa Korth in Rodent. J. Ethnopharmacol. 2010, 131, 404-409. [CrossRef] [PubMed]

56. Sasidharan, S.; Kwan, Y.; Latha, L.; Rajeh, M.A.; Zakaria, Z.; Jothy, S. Acute toxicity impacts of Euphorbia hirta L extract on behavior, organs body weight index and histopathology of organs of the mice and Artemia salina. Pharmacognosy Res. 2012, 4, 170. [CrossRef] [PubMed]

57. Teo, S.; Stirling, D.; Thomas, S.; Hoberman, A.; Kiorpes, A.; Khetani, V. A 90-day oral gavage toxicity study of d-methylphenidate and d,l-methylphenidate in Sprague-Dawley rats. Toxicology 2002, 179, 183-196. [CrossRef]

58. Chavalittumrong, P.; Attawish, A.; Rugsamon, P.; Chuntapet, P. Toxicological study of Clinacanthus nutans (Burm.f.) Lindau. Bull. Dep. Med. Sci. 1995, 37, 323-338.

59. Cajuday, L.A.; Pocsidio, G.L. Effects of Moringa oleifera Lam. (Moringaceae) on the reproduction of male mice (Mus musculus). J. Med. Plants Res. 2010, 4, 1115-1121. 
60. Fazliana, M.S.; Muhajir, H.; Hazilawati, H.; Shafii, K.; Mazleha, M. Effects of Ficus deltoidea aqueous extract on hematological and biochemical parameters in rats. Med. J. Malaysia 2008, 63, 103-104.

61. Archibong, A.; Ofem, O.; Nna, V.; Bisong, E.; Johnson, J.; Eno, A. Changes in Haematological Parameters Following the Administration of Crude Extract from Tympanotonus fuscatus (Periwinkle) in Rats. Aust. J. Basic Appl. Sci. 2014, 8, 586-591.

62. Tønnesen, H.; Hejberg, L.; Frobenius, S.; Andersen, J.R. Erythrocyte Mean Cell Volume-Correlation to Drinking Pattern in Heavy Alcoholics. Acta Med. Scand. 2009, 219, 515-518. [CrossRef]

63. Ross, D.W.; Bentley, S.A. Evaluation of an automated hematology system (Technicon H-1). Arch. Pathol. Lab. Med. 1986, 110, 803-808. [PubMed]

64. Gad, M.M.E.-S.; Mohammad, Y.S.; Mohammad, T.G.M. Acute and Repeated-Doses (28 Days) Toxicity of Thymol Formulation in Male Albino Rats. Aust. J. Basic Appl. Sci. 2013, 7, 915-922.

65. Evans, G. Animal Clinical Chemistry, 2nd ed.; Evans, G.O., Ed.; CRC Press: Boca Raton, FL, USA, 2009; ISBN 9780429141690.

66. Braun, J.-P.; Lefebvre, H.P. Kidney Function and Damage. In Clinical Biochemistry of Domestic Animals; Elsevier: Amsterdam, The Netherlands, 2008; pp. 485-528. ISBN 9780123704917.

67. Rhiouani, H.; El-Hilaly, J.; Israili, Z.H.; Lyoussi, B. Acute and sub-chronic toxicity of an aqueous extract of the leaves of Herniaria glabra in rodents. J. Ethnopharmacol. 2008, 118, 378-386. [CrossRef] [PubMed]

68. Dina, P.F.; Hazilawati, H.; Rosly, S.M.; Shanmugavelu, S.; Noordin, M.M. Expression of circulating CD146 associated with endovascular dysfunction in adenine-induced chronic renal damage in rats using an evagreen real-time RT-PCR assay. Pertanika J. Trop. Agric. Sci. 2011, 34, 381-391.

69. Pariyani, R.; Ismail, I.S.; Azam, A.; Khatib, A.; Abas, F.; Shaari, K.; Hamza, H. Urinary metabolic profiling of cisplatin nephrotoxicity and nephroprotective effects of Orthosiphon stamineus leaves elucidated by $1 \mathrm{H}$ NMR spectroscopy. J. Pharm. Biomed. Anal. 2017, 135, 20-30. [CrossRef]

70. Tan, C.X.; Chong, G.H.; Hamzah, H.; Ghazali, H.M. Hypocholesterolaemic and hepatoprotective effects of virgin avocado oil in diet-induced hypercholesterolaemia rats. Int. J. Food Sci. Technol. 2018, 53, 2706-2713. [CrossRef]

71. Bantel, H.; Schulze-Osthoff, K. Mechanisms of Cell Death in Acute Liver Failure. Front. Physiol. 2012, 3, 1-8. [CrossRef]

72. Hinson, J.A.; Roberts, D.W.; James, L.P. Mechanisms of Acetaminophen-Induced Liver Necrosis. In Handbook of Experimental Pharmacology; Springer: New York, NY, USA, 2010; pp. 369-405. ISBN 9783642006623.

73. Mahdi, H.J.; Yousif, E.M.; Khan, N.A.K.; Mahmud, R.; Murugaiyah, V.A.; Asmawi, M.Z. Bin Optimizing Extraction Conditions of Moringa oleifera Lam Leaf for Percentage Yeild, Total Phenolics content, Total Flavonoids Content and Total Radical Scavenging Activity. Int. J. Adv. Res. 2015, 4, 682-695. [CrossRef]

74. Aliyu, A.; Alkali, B.R.; Yahaya, M.S.; Garba, A.; Adeleye, S.A.; Gashua, M.M.; Sa'Adatu, I.; Gugong, V.; Daneji, A.I. Phytochemical analysis and antibacterial activity of Khaya senegalensis bark extracts on Bacillus subtilis, Escherichia coli and Proteus mirabilis. Int. J. Phytomedicine 2016, 8, 333-336. [CrossRef]

75. Annegowda, H.V.; Bhat, R.; Min-tze, L.; Karim, A.A.; Mansor, M.S. Influence of sonication treatments and extraction solvents on the phenolics and antioxidants in star fruits. J. Food Sci. Technol. 2012, 49, 510-514. [CrossRef]

76. Othman, A.; Ismail, A.; Abdul Ghani, N.; Adenan, I. Antioxidant capacity and phenolic content of cocoa beans. Food Chem. 2007, 100, 1523-1530. [CrossRef]

77. Abdul-Hamid, N.A.; Abas, F.; Ismail, I.S.; Shaari, K.; Lajis, N.H. Influence of Different Drying Treatments and Extraction Solvents on the Metabolite Profile and Nitric Oxide Inhibitory Activity of Ajwa dates. J. Food Sci. 2015, 80, H2603-H2611. [CrossRef] [PubMed]

78. Mahdi, H.; Yousif, E.; Khan, N.; Mahmud, R.; Murugaiyah, V.; Asmawi, M. Optimizing Extraction Conditions of Moringa oleifera Lam Leaf for Percent Yield, Total Phenolics Content, Total Flavonoids Content and Total Radical Scavenging Activity. Int. J. Adv. Res. 2016, 4, 682-695. [CrossRef]

79. Kasolo, J.N.; Bimenya, G.S.; Ojok, L.; Ogwal-Okeng, J.W. Sub-acute toxicity evaluation of Moringa oleifera leaves aqueous and ethanol extracts in Swiss Albino rats. Int. J. Med. Plant Res. 2012, 1, 074-081.

80. Coppin, J.P.; Xu, Y.; Chen, H.; Pan, M.H.; Ho, C.T.; Juliani, R.; Simon, J.E.; Wu, Q. Determination of flavonoids by LC/MS and anti-inflammatory activity in Moringa oleifera. J. Funct. Foods 2013, 5, 1892-1899. [CrossRef]

81. Held, H.E.; Pilla, R.; Ciarlone, G.E.; Landon, C.S.; Dean, J.B. Female rats are more susceptible to central nervous system oxygen toxicity than male rats. Physiol. Rep. 2014, 2, e00282. [CrossRef] 
82. Awodele, O.; Oreagba, I.A.; Odoma, S.; Teixeira Da Silva, J.A.; Osunkalu, V.O. Toxicological evaluation of the aqueous leaf extract of Moringa oleifera Lam. (Moringaceae). J. Ethnopharmacol. 2012, 139, 330-336. [CrossRef]

83. Serfilippi, L.M.; Pallman, D.R.S.; Russell, B. Serum clinical chemistry and hematology reference values in outbred stocks of albino mice from three commonly used vendors and two inbred strains of albino mice. Contemp. Top. Lab. Anim. Sci. 2003, 42, 46-52.

84. Aliyu, A.; Shaari, M.R.; Ahmad Sayuti, N.S.; Reduan, M.F.H.; Sithambaram, S.; Noordin, M.M.; Shaari, K.; Hamzah, H. N-Ethyl- $n$-Nitrosourea Induced Leukaemia in a Mouse Model through Upregulation of Vascular Endothelial Growth Factor and Evading Apoptosis. Cancers 2020, 12, 678. [CrossRef]

85. Charles, E.W.; Ruben, D.S.; Franklin, C. Complete blood count, clinical chemistry, and serology profile by using a single tube of whole blood from mice. J. Am. Assoc. Lab. Anim. Sci. 2007, 46, 59-64.

86. Aliyu, A.; Natala, A.J.; Adamu, S.; Igbokwe, I.O.; Esievo, K.A.N.; Useh, N.M. A Comparative Study on the Haematology, Biochemical Alterations in Serum Composition and Pathologic Changes in the Kidneys of Cachectic and Non-cachectic Cattle in Zaria, Nigeria. Int. J. Biochem. Res. Rev. 2017, 19, 1-11. [CrossRef] [PubMed]

87. Kodentsova, V.M.; Vrzhesinskaya, O.A.; Beketova, N.A.; Soto, S.K.; Karagodina, Z.V.; Sharanova, N.E.; Baturina, V.A. Biochemistry of Blood Plasma and Some Parameters of Antioxidant Status in Rats with Polyhypovitaminosis of Varying Severity. Bull. Exp. Biol. Med. 2013, 154, 445-448. [CrossRef] [PubMed]

88. Fernandes, D.P.; Pimentel, M.M.L.; Dos Santos, F.A.; Praxedes, É.A.; De Brito, P.D.; Lima, M.A.; Lelis, I.C.N.G.; De Macedo, M.F.; Bezerra, M.B. Hematological and biochemical profile of BALB/c nude and C57BL/6 SCID female mice after ovarian xenograft. An. Acad. Bras. Cienc. 2018, 90, 3941-3948. [CrossRef] [PubMed]

89. Al-Shabanah, O.A.; El-Hadiyah, T.M.; Al-Majed, A.A. Effect of prolonged vigabatrin treatment on hematological and biochemical parameters in plasma, liver and kidney of Swiss albino mice. Sci. Pharm. 2002, 70, 135-145.

90. Keppler, A.; Gretz, N.; Schmidt, R.; Kloetzer, H.-M.; Groene, H.-J.; Lelongt, B.; Meyer, M.; Sadick, M.; Pill, J. Plasma creatinine determination in mice and rats: An enzymatic method compares favorably with a high-performance liquid chromatography assay. Kidney Int. 2007, 71, 74-78. [CrossRef]

91. Nurul, S.A.S.; Hazilawati, H.; Mohd, R.S.; Mohd, F.H.R.; Noordin, M.M.; Norhaizan, M.E. Subacute Oral Toxicity Assesment of Ethanol Extract of Mariposa christia vespertilionis Leaves in Male Sprague Dawley Rats. Toxicol. Res. 2018, 34, 85-95. [CrossRef]

Sample Availability: Samples of the compounds are not available from the authors.

(C) 2020 by the authors. Licensee MDPI, Basel, Switzerland. This article is an open access article distributed under the terms and conditions of the Creative Commons Attribution (CC BY) license (http://creativecommons.org/licenses/by/4.0/). 